\title{
Proteins as Promising Biobased Building Blocks for Preparing Functional Hybrid Protein/Synthetic Polymer Nanoparticles
}

\author{
Luisa G. Cencha, Mariana Allasia, Ludmila I. Ronco, Gisela C. Luque, Matías L. Picchio, \\ Roque J. Minari,* and Luis M. Gugliotta*
}

Cite This: Ind. Eng. Chem. Res. 2021, 60, 4745-4765

Read Online

ACCESS I

山lll Metrics \& More

回 Article Recommendations

ABSTRACT: The pursuit of sustainable and environmentally friendly materials has been powered by environmental concerns and the decline in oil reserves. Among the different routes toward this end, the replacement of oil-based materials by renewable materials stands out. In this way, protein based materials have gained interest. This review article summarizes the progress achieved in the synthesis of hybrid protein/synthetic polymer nanoparticles which have the potential to be used in industrial applications. Although technical achievements and efficacy proofs concerning the increased compatibility of polymer/protein are already available, practical implementation in industry still represents an additional challenge and should be the focus of interest in future research. The available literature supports the potential of hybrid protein/polymer nanoparticles in the production of ecofriendly alternatives for large scale applications as coatings, paints, adhesives and films.

\section{INTRODUCTION}

Polymer materials available today are the result of decades of evolution. In the last decades, the polymer industry has made significant efforts to develop environmentally friendly processes that prevent the emission of volatile organic compounds (VOCs). In this context, waterborne polymers, such as latexes, appear as an ecological alternative to solventborne resins and occupy a key role in many industries as coatings, paints, adhesives, impact modifiers, inks, packaging, rubber, and so on. ${ }^{1,2}$ Furthermore, waterborne latexes in film applications have additional advantages over solvent-borne alternatives, such as faster drying times, less smell, and easier clean up. ${ }^{3,4}$ Additionally, waterborne polymer dispersions are obtained by emulsion polymerization (EP) or miniemulsion polymerization (MEP). This presents several advantages in comparison with processes carried out in bulk or in organic solvents due to the use of water as continuous phase. The environmental friendliness and safety of these polymers are ensured due to the high heat capacity and low viscosity of the emulsion. Thus, the EP process was created and nowadays it is a widespread technique to produce at large scale high-quality materials in a consistent, safe, and environmentally friendly way, with a worldwide production of polymer material of more than 25 million tonnes/year. ${ }^{5,6}$ It is forecasted that the global market for waterborne dispersions will increase its value from USD 7.6 billion (2019) to USD 11.8 billion (2027). ${ }^{7}$ Despite the many advantages of waterborne latexes, most of the industrially synthesized dispersed polymers are based on petroleum-based monomers. In recent years, instability of petroleum prices, consumer demands, environmental concerns, and strict regulations about gas emissions have pushed academics and industries toward the development of sustainable and environmentally friendly materials. In this scenario, there is an interest for replacing current petroleumbased polymers by renewable and more sustainable feedstocks aiming to reduce the carbon footprint of this industry and ensure a circular economy. ${ }^{8}$ In the last decade, many substitution alternatives have been investigated, involving copolymerization of biobased monomers, ${ }^{9}$ incorporation of biobased preformed polymers such as alkyds, ${ }^{10-13}$ and biopolymers as carbohydrates, ${ }^{14,15}$ natural rubber, ${ }^{16}$ proteins, ${ }^{17}$ and lignocellulosic biomass. ${ }^{18-20}$ Among the alternatives for substituting petroleum-based polymers, natural proteins represent a promising option due to their superior biodegradability, edibility, low toxicity, convenient absorbability, and in

Received: December 3, 2020

Revised: March 12, 2021

Accepted: March 15, 2021

Published: March 26, 2021 


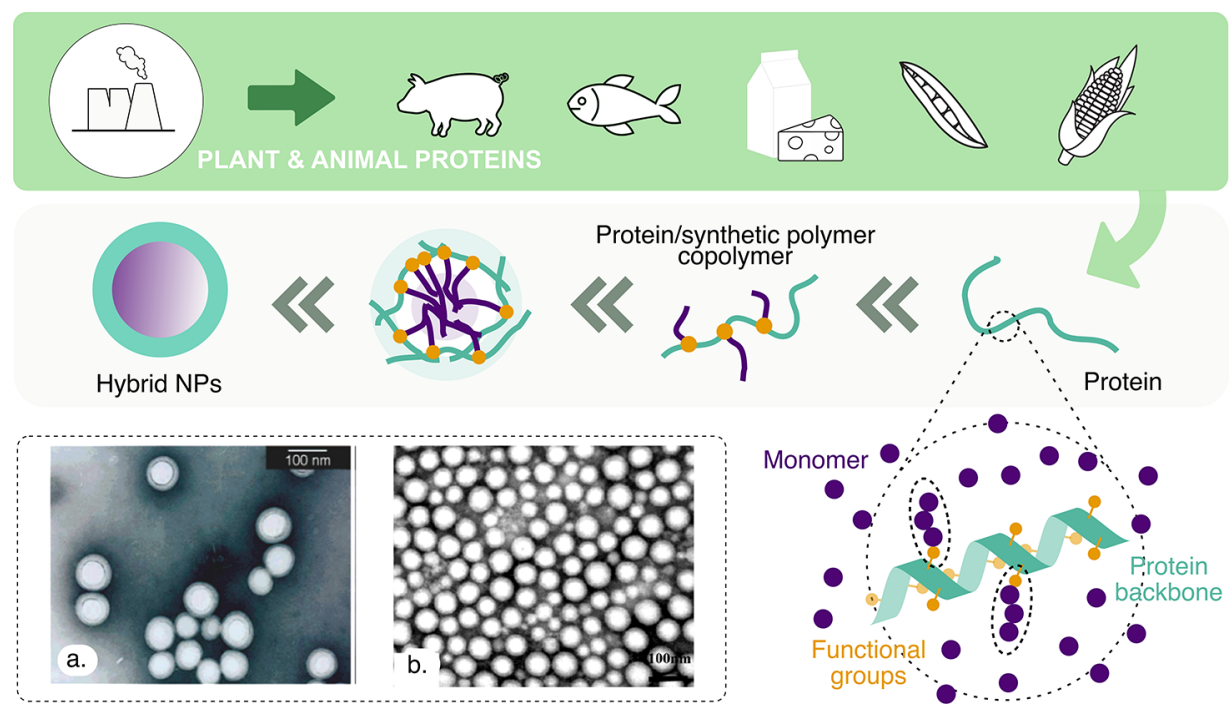

Figure 1. Scheme of the process for producing hybrid protein/polymer NPs. Plant protein and animal protein, usually byproducts or even effluents of others industries, represent a high-potential feedstock to reduce the use of petroleum-based monomers. Waterborne latexes of hybrid NPs are mainly produced by the EP of monomers in the presence of proteins. The inset shows two examples of hybrid NPs produced through EP. (a) Casein/poly(methyl methacrylate). Figure reprinted in part from ref 79. Copyright 2002 American Chemical Society. (b) Caprolactam-modified casein/poly(butyl acrylate). Reproduced with permission from ref 67. Copyright 2013 Elsevier.

Table 1. Characteristics and Comparison of the Main Proteins Included in Hybrid Protein/Synthetic Polymer NPs with Potential to Be Used in Industrial Applications as Functional Materials. The Main Uses Refer to Pure Proteins

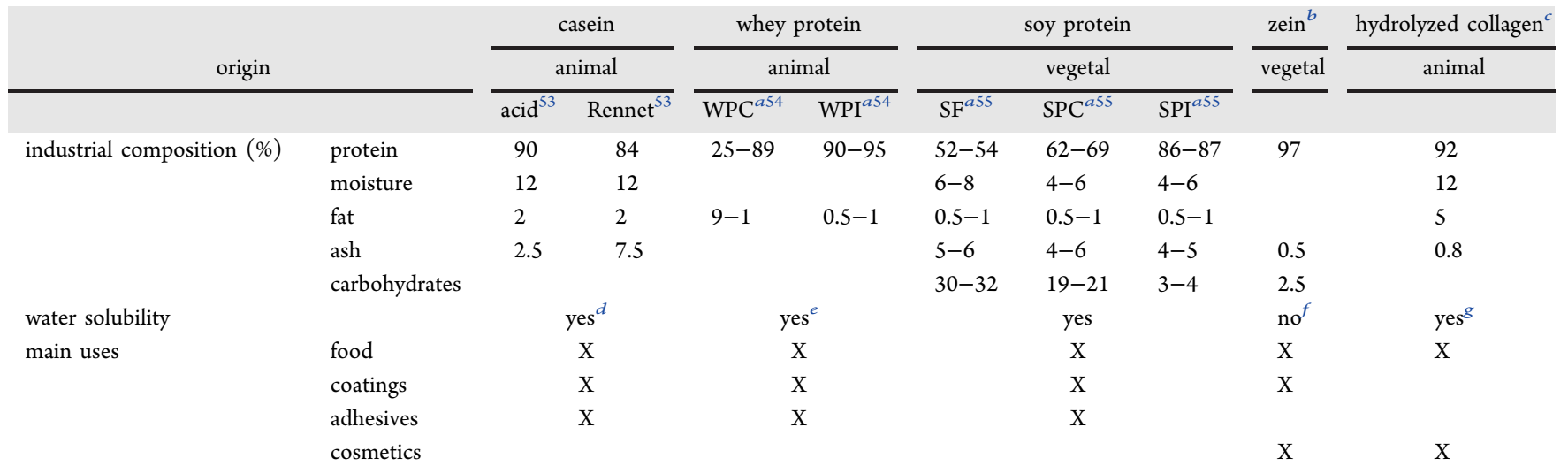

${ }^{a}$ WPC: whey protein concentrate; WPI: whey protein isolate; SF: soy flour; SPC: soy protein concentrate; SPI: soy protein isolate. ${ }^{b}$ Composition of zein extracted from corn gluten meal and determined on an anhydrous base. ${ }^{56}{ }^{c}$ Composition of commercial bovine gelatin. ${ }^{57 d}$ Soluble for $\mathrm{pH}>$

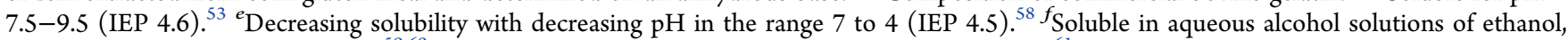

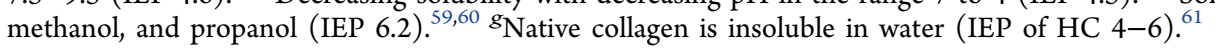

many cases high availability at good purity and low cost. ${ }^{21,22}$ In addition, proteins contain functionalities such as amine, carboxyl, hydroxyl, and thiol, which provide opportunities for introducing structure modifications. ${ }^{23,24}$ Functionalities available in proteins are also interesting to design hybrid materials with engineered surfaces in order to have specific properties, that is, wettability, adhesion or fouling. ${ }^{25-27}$ One limitation of feedstock proteins is the lack of uniformity typically found in natural materials. However, proteins are usually underused, which adds up to the aforementioned advantages to make these biopolymers a promising eco-friendly raw material (Figure 1). Nowadays, several proteins such as casein (CA), collagen derivative proteins, and zein are employed in many film forming applications at the industrial level as adhesives, leather finishing agents, and in paper coating. These materials present as a main drawback a low resistance to microbial attack and to wet rub, and a reduced flexibility and extensibility, ${ }^{28}$ and for this reason protein conjugation with a synthetic polymer appears as the main explored alternative for facing this issue. The synthesis of hybrid latexes containing proteins has gained technological and also biomedical interest because of the possibilities to modify and improve the properties of these natural substances by incorporating synthetic polymers. ${ }^{29-31}$

Diverse composite materials including proteins and certain organic/inorganic materials such as metals, ${ }^{32-36}$ clay, $^{37-39}$ semiconductors, ${ }^{40,41}$ different types of polymers, ${ }^{42,43}$ and more have been reported. ${ }^{44,45}$ Also, the inclusion of proteins in polymeric particles has been extensively investigated and widely addressed in several recent reviews, ${ }^{46-52}$ focusing on biomedical applications and on the therapeutic role of the employed protein (immunodiagnostic testing, gene treatment, enzymes immobilization, and controlled release, among others). However, these works did not include waterbone high protein-content particles obtained by a scalable process, 
Table 2. Summary of Protein/Synthetic Polymer Nanoparticles

\begin{tabular}{|c|c|c|c|c|c|c|c|}
\hline protein & protein modification & $\begin{array}{l}\text { synthetic } \\
\text { monomer }\end{array}$ & synthesis process/initiators & $\mathrm{PC}(\%)$ & $\begin{array}{l}\text { particle } \\
\text { diameter } \\
(\mathrm{nm})\end{array}$ & $\begin{array}{l}\text { applications and } \\
\text { potential uses }\end{array}$ & ref \\
\hline \multirow[t]{19}{*}{ casein } & neat & MMA & $\mathrm{EF}-\mathrm{EP} / \mathrm{Cu}(\mathrm{II})$ & $100-20$ & 96 & $\begin{array}{l}\text { leather finishing } \\
\text { textiles industries } \\
\text { biocompatible } \\
\text { materials }\end{array}$ & 95 \\
\hline & neat & MMA & EF-EP/TBHP & 25 & 82 & nonspecified & 79 \\
\hline & neat & MMA & EF-EP/TBHP & 25 & 83 & nonspecified & 99 \\
\hline & & & EF-EP/KPS & & 74 & & \\
\hline & & & EF-EP/V-50 & & 70 & & \\
\hline & & & EF-EP/AIBN & & 69 & & \\
\hline & & & EF-EP/BPO & & & & \\
\hline & & & EF-EP/TBP & & & & \\
\hline & neat & MMA & EF-EP/TBHP & $3-50$ & $162-113$ & nonspecified & 24 \\
\hline & neat & $\mathrm{BA} / \mathrm{MMA}$ & EF-EP/TBHP & $3-50$ & $194-122$ & $\begin{array}{l}\text { waterborne } \\
\text { coatings }\end{array}$ & 100 \\
\hline & HMC & $\mathrm{BA} / \mathrm{MMA}$ & EF-EP/TBHP & 50 & $165-218$ & $\begin{array}{l}\text { waterborne } \\
\text { coatings }\end{array}$ & 82 \\
\hline & CPL-modified & WPU & blend, hydrogen bonds & $900-100$ & $77-46$ & leather finishing & 66 \\
\hline & & & & & & $\begin{array}{l}\text { film-forming } \\
\text { material }\end{array}$ & \\
\hline & CPL-modified & BA & EF-EP/APS & 70 & & leather finishing & 67 \\
\hline & & & EF-EP/KPS & & & & \\
\hline & & & $\mathrm{EF}-\mathrm{EP} / \mathrm{APS}+\mathrm{NaHSO}_{3}$ & & & & \\
\hline & & & $\mathrm{EF}-\mathrm{EP} / \mathrm{KPS}+\mathrm{NaHSO}_{3}$ & & 80 & & \\
\hline & CPL-modified & $\mathrm{VAC} / \mathrm{BA} / \mathrm{AM}$ & $\mathrm{EP} / \mathrm{APS}$ & $30-55$ & $40-50$ & $\begin{array}{l}\text { waterborne printing } \\
\text { ink } \\
\text { leather finishing } \\
\text { coatings }\end{array}$ & 84 \\
\hline & CPL-modified & $\begin{array}{l}\text { BA/MMA/ } \\
\text { PDMS }\end{array}$ & EF-EP/APS & & 50 & $\begin{array}{l}\text { textiles } \\
\text { food packaging }\end{array}$ & 72 \\
\hline $\begin{array}{l}\text { whey } \\
\text { protein }\end{array}$ & denatured & PVAc & $\begin{array}{l}\text { blending and cross-linking with } \\
\text { MDI }\end{array}$ & 30 & & adhesives & 120 \\
\hline \multirow[t]{8}{*}{ soy } & neat & MMA & EF-EP/KPS & & & packaging & 124 \\
\hline & neat & St & EP (emulsifier:SDS)/KPS & $200-2000$ & $10-30$ & $\begin{array}{l}\text { thermoplastic } \\
\text { hybrid materials }\end{array}$ & 125 \\
\hline & & & & & & $\begin{array}{l}\text { poly(styrene) } \\
\text { substitute }\end{array}$ & \\
\hline & $\begin{array}{l}\text { neat/treated with } \mathrm{NaOH} \\
\text { solution }\end{array}$ & $\mathrm{BA} / \mathrm{MMA}$ & $\begin{array}{l}\text { MEP (emulsifiers: alkylphenol } \\
\text { ethoxylates and SLS) }\end{array}$ & $1.2-6.2$ & & wood adhesives & 126 \\
\hline & acylation with NHS & $\mathrm{AM} / \mathrm{AA}$ & RAFT polymerization & 10,50 & $66-162$ & $\begin{array}{l}\text { synthetic hybrid } \\
\text { latexes }\end{array}$ & 127 \\
\hline & $\begin{array}{l}\text { treated with } \mathrm{NH}_{4} \mathrm{OH} \\
\text { solution }\end{array}$ & $\begin{array}{l}\text { diene and vinyl } \\
\text { monomers }\end{array}$ & EF-EP/oil soluble azo initiators & $11-43$ & $\begin{array}{l}\text { paper } \\
\text { coatings }\end{array}$ & 128 & \\
\hline & neat/carboxylated & Vinyl monomers & EF-EP/azo initiator & $4-60$ & $90-600$ & $\begin{array}{l}\text { organic pigments } \\
\text { paper coating }\end{array}$ & 129 \\
\hline & $\begin{array}{l}\text { functionalization with } N \text { - } \\
\text { methylolacrylamide }\end{array}$ & St & EP/APS & $535-2674$ & & wood adhesives & 130 \\
\hline \multirow[t]{2}{*}{ collagen } & $\mathrm{HC}$ & $\mathrm{AA} / \mathrm{BA}$ & $\mathrm{EF}-\mathrm{EP} / \mathrm{H}_{2} \mathrm{O}_{2}$ & $15-50$ & $500-880$ & bioadhesives & 131 \\
\hline & neat & MMA & EF-EP/TBHP & 25 & 160 & nonspecified & 79 \\
\hline zein & neat zein/HMC & BA/MMA & EF- MEP/TBHP & $\begin{array}{l}5 \%(25 \% \text { total } \\
\text { protein })\end{array}$ & 209 & $\begin{array}{l}\text { waterborne } \\
\text { coatings }\end{array}$ & 132 \\
\hline
\end{tabular}

which represents a current challenge for producing new ecofriendly latexes for novel applications or as alternative for well-established uses. Nevertheless, this article revises the recent advances on hybrid nanoparticles (NPs) composed of proteins and synthetic polymers with the main goal of improving the sustainability of the industrial development of waterborne particles at different large-scale applications such as coatings, adhesives, films, paintings, papermaking, etc. In this context, this review includes the main characteristics of the employed proteins, the proposed strategies of synthesis, and the involved mechanisms for producing different protein/ synthetic polymer hybrid NPs. Moreover, the main features of the considered hybrid NPs are here revised, including their size, protein content, and the degree of compatibilization of the protein/polymer phases. The synthesis routes of the hybrid NPs are analyzed, and a general mechanism for protein-based particles formation is proposed, which involves emulsifier-free emulsion polymerization (EF-EP) as the most preferred process. Moreover, the advances on protein modifications which have proved to increase the compatibility between protein and synthetic polymer, resulting in an improvement in the final properties of the hybrid materials, are emphasized. 
Finally, the main future perspectives and opportunities of proteins-based NPs are outlined.

Proteins as Functional Constituent of Hybrid NPs. There is a vast assortment of proteins which have been used in the manufacture of several composite materials. Because of their main features, proteins find most of their applications in the field of medicine and bioengineering. In this review, however, the focus relies on polymer/protein hybrid NPs which have the potential to be industrially applied as functional materials. With this aim, the proteins overviewed here are milk proteins (casein and whey protein), soy protein, collagen, and zein. A few more examples including other proteins can be found at the end of this section. A comparison of the origin, industrial composition, water solubility, and main uses of the proteins as raw materials of these mentioned biobuilding blocks are summarized in Table 1.

The ultimate goal of protein incorporation into latex formulations is the decline in environment pollution and the increase in biodegradability without degrading the good performance of the synthetic polymers. Therefore, a key factor which defines the industrial scalability of the hybrid latexes is the protein content of the NPs. On the other hand, the performance of the hybrid NPs is the result of the balance between the properties of the protein and those of synthetic polymers, which is expected to be optimized when a compatible system is achieved, that is, when protein and polymer remain in intimate contact. Indeed, the microstructure of the hybrid protein/synthetic polymer involves different species, which give place to the formation of multiphase NPs, including the synthetic polymer, the free protein, and the copolymer containing both components chemically bonded (mostly by grafting). With the aim of comparing and discussing the molecular characteristics of these different materials, three parameters are here defined and will be used throughout this review: (i) protein content (PC) based on a synthetic monomer (eq 1), (ii) degree of grafting of a synthetic polymer (GSP, eq 2), and (iii) degree of grafting of protein (GP, eq 3). Note that, GSP and GP are a measure of the degree of compatibility between both materials (protein and synthetic polymer) in the NPs.

$$
\begin{aligned}
& \text { PC }=\frac{\text { wt of loaded protein }}{\text { wt of total loaded synthetic monomer }} \\
& \text { GSP }=\frac{\text { wt of grafted synthetic polymer }}{\text { wt of total synthetic polymer }} \\
& \mathrm{GP}=\frac{\text { wt of grafted protein }}{\text { wt of total loaded protein }}
\end{aligned}
$$

Several works including the synthesis or the development of tools with potential for obtaining hybrid protein/polymer NPs are presented next for the aforementioned proteins. A summary of the total content of protein, employed monomers, and main latex properties of the more representative works are presented in Table 2.

Casein. Casein represents $\sim 80 \%$ of the proteins in bovine milk, ${ }^{62}$ and corresponds to the fraction precipitated when unheated (raw) milk is acidified to $\mathrm{pH} 4.6$ (isoelectric point, IEP). The protein remnant in solution corresponds to whey proteins. Acid casein is precipitated from skim milk by acidification; on the other hand rennet casein is obtained when the milk is treated with rennet. Casein world production, together with caseinates, is estimated between 430.000 and 460.000 tonnes, with New Zealand, The Netherlands, and Germany being its main producers. ${ }^{53}$ Casein can be further classified as edible or industrial. The latter is estimated to reach $90.2 \%$ of the total global casein and caseinate market in 2025, followed by edible grade casein with $9.8 \%{ }^{63}$

Owing to its excellent film-forming capability and good adhesive properties, casein was used as long as thousands of years ago. Nowadays, neat casein and modified casein still find applications in coatings, adhesives, papermaking, leather finishing, and edible films, among others. ${ }^{64-73}$ Moreover, due to its biocompatibility and nonimmunogenic characteristics, casein is a striking material to be used in gene-delivery therapies and drug delivery applications. ${ }^{52,74-76}$ However, industrial applications of casein are limited mainly due to its poor water-resistance and mechanical strength. A promising approach to tackle these drawbacks is taking advantage of the high quantity of polar groups present in the structure of casein molecules, such as amino, hydroxyl, and carboxyl groups, which give casein the ability to generate physical interactions in blends with other materials, and to be chemically modified by grafting with natural or synthetic polymers. ${ }^{73}$ Both inorganic $^{73,77,78}$ and organic materials ${ }^{24,65,79-85}$ have been proposed to expand casein applicability.

The first published attempts to merge casein with synthetic polymers involved casein incorporation in the EF-EP of conventional monomers initiated with potassium persulfate (KPS) or ammonium persulfate (APS). ${ }^{86-92}$ The included monomers were butyl acrylate (BA), vinyl acetate (VAC), butyl methacrylate (BMA), acrylamide (AM), and methyl acrylate (MA), and the polymerizations were carried out in the presence of a wide range of casein amount $(\mathrm{PC} \approx 16-220 \%)$. Despite a grafting mechanism not being reported, it is expected that it involves an unspecific hydrogen abstraction from casein by the sulfate radical species. The grafting extent (measured as the fraction of synthetic polymer containing grafted protein) was studied, and it was found that the GSP increased with the concentrations of initiator, monomer, or casein. One limitation of this method is the use of persulfates initiators that may result in an oxidative degradation of casein, ${ }^{93,94}$ producing yellowish products.

These oxidative problems were overcame by $\mathrm{Li}$ et al. ${ }^{95}$ in the synthesis of casein/poly(methyl methacrylate) core-shell NPs, by grafting polymerized methyl methacrylate (MMA) onto casein, using a trace of copper ions as initiator $(\mathrm{PC}=20-$ $100 \%)$. The authors studied the influence of the copper ion/ casein ratio, finding 9.5/1000 as the optimum ratio, below which the conversion of MMA was considerably reduced, and above which particles became very unstable. These results suggested that casein interacts with copper ions to initiate the graft copolymerization of MMA, allowing the formation of core-shell NPs in the absence of surfactant (i.e., in an EF-EP). The latex particles exhibited a mean diameter of $96 \mathrm{~nm}$. Moreover, a typical kinetic behavior for radical polymerization confined in a preformed microenvironment was observed, which is in agreement with a radical polymerization mechanism involving complexes between the polymer and MMA on copper ion. ${ }^{96}$ A redox initiation approach was followed elsewhere to efficiently graft $\mathrm{BA}^{97}$ and $\mathrm{MMA}^{98}$ onto casein, using potassium diperiodatonickelate ( $\mathrm{Ni}(\mathrm{IV})$ ), and potassium ditelluratocuprate(III) (DTC), respectively, which form redox systems with casein. 
Moreover, another novel synthetic method to create casein/ polymer amphiphilic nanoparticles and overcome such oxidative problems of persulfate initiators was developed in the later works of $\mathrm{Li}$ and co-workers ${ }^{79,99}$ It consists of an EFEP in which an organic hydroperoxide $(\mathrm{ROOH})$ initiator, such as tert-butyl hydroperoxide (TBHP), reacts with the amino groups present in casein, generating radicals in their $\mathrm{N}$ atoms. ${ }^{79}$ The radicals formed onto casein amine groups initiate the graft copolymerization of MMA, and as these radicals become water insoluble they assemble into polymer NPs precursors. Following this mechanism, stable latexes with solid content up to $31 \%$ were produced, with a NPs diameter around $80 \mathrm{~nm}$, having a narrow particle size distribution, and covalent bonding between core (poly(methyl methacrylate) (PMMA)) and shell (casein), that is, compatibilized NPs. The PC and GSP were $25 \%$ and $40-50 \%$, respectively, while the grafting percentage of protein was not reported. ${ }^{79,99}$ Alternatively, a grafting percentage defined as the ratio between the weights of the grafted PMMA branches to the weight of loaded casein was reported to be $130-190 \%,{ }^{79,99}$ indicating that the synthetic polymer (PMMA) is the main component of the grafted material. It is worth noting that the authors of this proposal suggested that it is extendible to any water-soluble polymer chains containing amino groups. Moreover, the copolymers obtained are metal ion-free and surfactant-free, which is highly required for extending this method to many biological applications.

The EF-EP process ${ }^{79,99}$ was also applied by Picchio et al. ${ }^{24}$ to fabricate waterborne acrylic/casein NPs by using the redox initiation method proposed by $\mathrm{Li}$ et al. ${ }^{79}$ Afterward, Picchio et al. ${ }^{100}$ produced hybrid latexes of acrylic (BA/MMA)/casein NPs through EF-EP ${ }^{79,99}$ with the aim of characterizing the synthesis parameters, the NPs microstructure, and the properties of the films obtained from the hybrid latexes. The authors found that PC (ranged from 3 to 50\%) strongly affects the grafting percentage of protein, where GP values are reduced according to the increase of casein concentration (Figure 2a). In consequence, a lower casein content allows the formation of hybrid casein-based NPs with higher GP and increased compatibility. ${ }^{24}$ A proper content of casein improved the film hardness, resistance to organic solvents, and soil degradability, and the antiblocking property, without degrading the low minimum film formation temperature (MFFT) typical of acrylic binders for coatings. These results demonstrated that casein-based hybrid latexes are proper materials with potential for being used as binders in waterborne coatings.

However, one limiting factor for acrylic/casein hybrid films reaching a commercial scale is the obtained low GP values when high casein concentrations are used in the latex formulation, which is highly desirable for a better exploitation of this renewable resource. With the aim to maximize the GP, casein acrylation with acrylic acid (AA) was studied (see section Synthesis of Hybrid Protein Based NPs), but a low degree of protein modification was reached. ${ }^{101}$ A more robust approach to overcome this difficulty was the use of highly methacrylated casein (HMC) in the latexes formulation, ${ }^{81,82,102}$ which can be obtained through an amine-glycidyl ether reaction. ${ }^{81}$ With this last procedure, the GP of the hybrid system was controlled by varying the content of methacrylic groups in the casein backbone. HMC containing up to 40 methacrylic groups per protein molecule (theoretical value) was synthesized achieving a GP as high as $82 \%,{ }^{82}$ which highly overpassed the $10 \%$ obtained through the traditional grafting
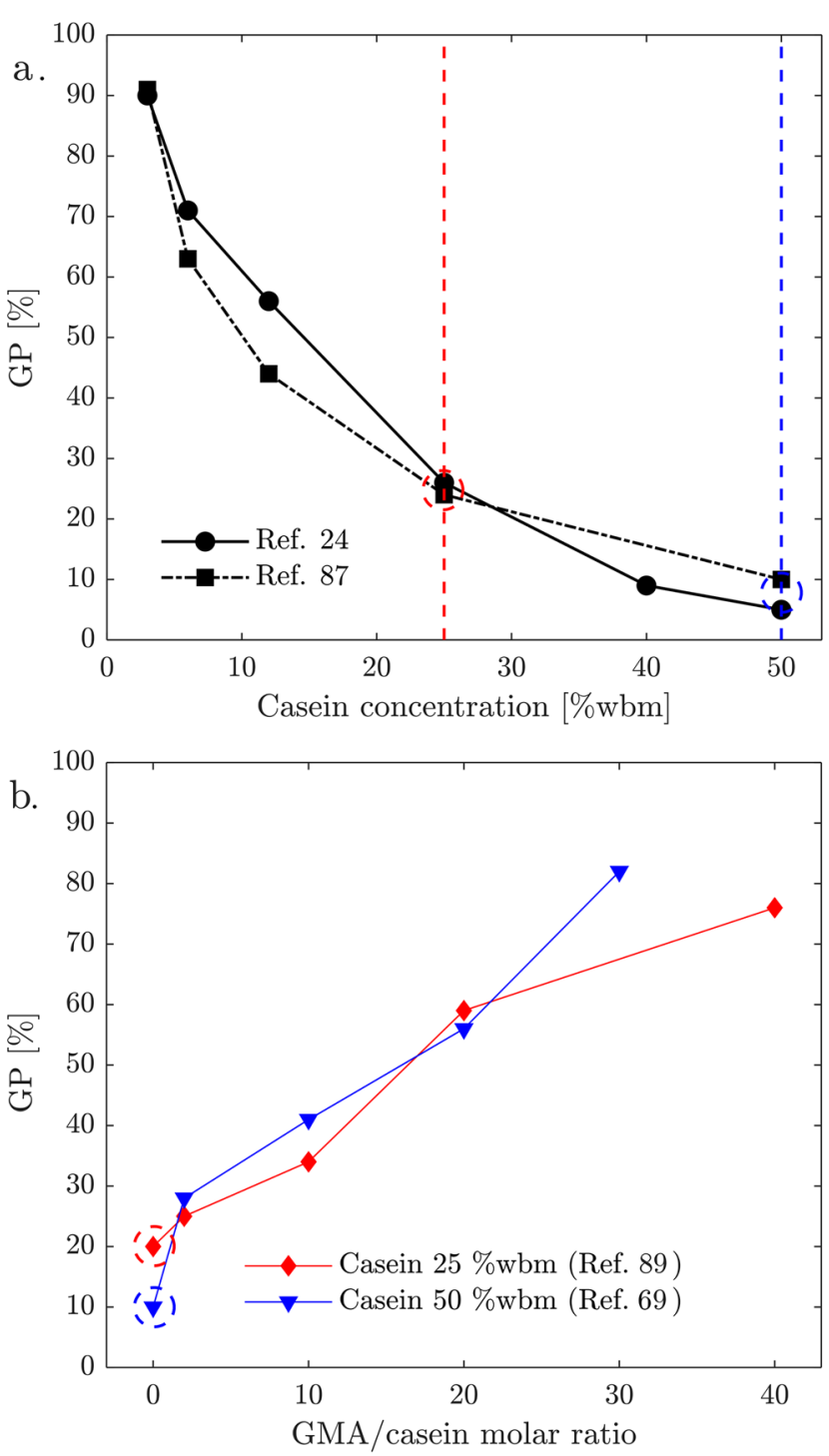

Figure 2. Effect of the casein concentration on the GP when using neat casein in the polymerization of $\mathrm{MMA}^{24}$ and in the copolymerization of MMA/BA ${ }^{100}$ (a), compared with the use of HMC (as a function of the methacrylation degree) in the copolymerization of MMA/BA for casein concentrations of 25 and $50 \%$ (b) ${ }^{82,102}$ The dashed lines in panel a indicate the casein concentrations for which the use of HMC is shown in panel b. The solid content in these latexes was $30 \%$.

method by redox initiation. ${ }^{100}$ A comparison of these values can be found in Figure $2 \mathrm{~b}$. Films obtained from high-solids content hybrid HMC/acrylic latexes exhibited more homogeneous phase distribution, increased water resistance, and improved block-resistance and open-times comparable to those of organic-solvent based paints (30-40 min). Besides these properties, optimized clear coat formulations with $\mathrm{HCM}$ /acrylic hybrid latexes as binders showed also good performance with minimal additive requirements, which expands the possibilities of using these latexes as waterborne eco-friendly binders in industrial applications. ${ }^{81,82,102}$

The potential use as adhesives of hybrid HMC/acrylic latexes prepared via the EF-EP route was studied by Aguzin et al. ${ }^{83}$ The PC was varied between 5 and $30 \%$, with a solid content of $35 \%$. Moreover, the performance of the final 


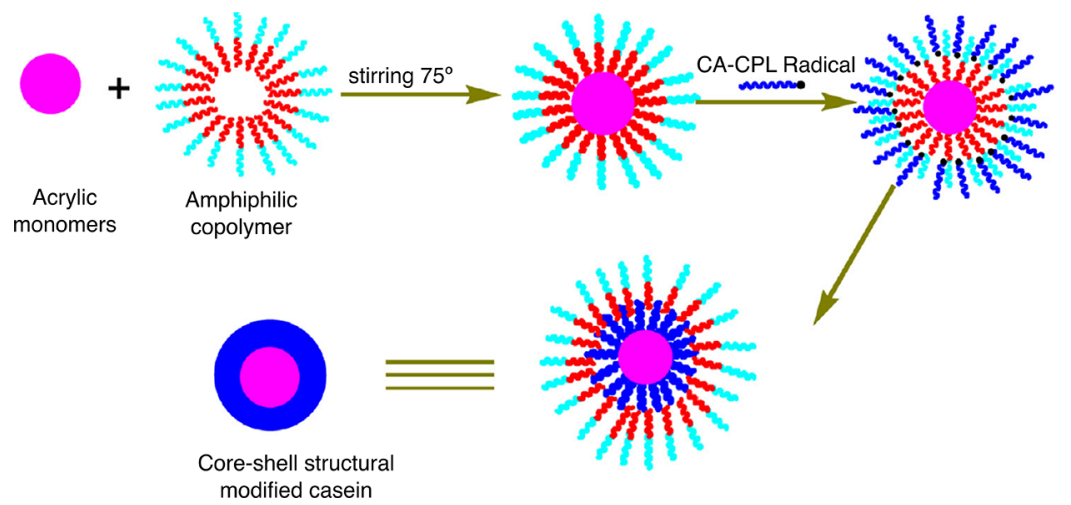

Figure 3. Scheme of the synthesis strategy of CA-CPL/acrylate core-shell NPs via EP. Reprinted with permission from ref 84 . Copyright 2015 Elsevier.

product produced with neat casein was tested against the use of HMC. Besides maintaining a good adherence of surfaces over time, commercial adhesives are required to be easily removable. For this reason, the removal capacity in alkaline conditions of the hybrid films was tested. It was found that the increased compatibility between the protein and the synthetic polymer, attained by using HMC instead neat casein, resulted in increased removal ability.

A different alternative for casein modification was explored by $\mathrm{Ma}$ and co-workers. ${ }^{65-67,72}$ These authors studied the ability of caprolactam-modified casein (CA-CPL) to form hybrid protein/polymer NPs in order to achieve an improved applicability as leather finishing agent and film-forming material, without losing its eco-friendly feature. CA-CPL has been used as a leather finishing agent despite having a limited flexibility and water repellency. Ma et al. ${ }^{66}$ have blended waterborne polyurethane (WPU) with CA-CPL to produce hybrid NPs mainly formed by the existence of hydrogen bonds between the urethane groups in the WPU and the CA-CPL particles. Particles diameters between 77 and $46 \mathrm{~nm}$ were obtained, depending on the WPU/CA-CPL mass ratio used (PC $=900-100 \%)$. The NPs showed improved hydrophobicity and reduced air permeability when compared with CA-CPL particles. Moreover, a superior flexibility and wet-rub resistance was obtained. These characteristics, added up to an acceptable biodegradability, making CA-CPL/WPU NPs a promising eco-friendly film-forming material.

Later, the same authors proposed a second approach to improve CA-CPL performance, preparing latexes with a coreshell structure of modified casein/BA via EF-EP. ${ }^{67}$ In this case, the PC was $70 \%$. The effect of different initiators was studied, resulting in the highest grafting extent of monomers for the redox pair $\mathrm{KPS}-\mathrm{NaHSO}_{3}$. Particles with a mean diameter of $80 \mathrm{~nm}$ were obtained, where CPL was the key to forming stable latex particles in the free-emulsifier process. Furthermore, the films exhibited a better hydrophobicity when compared to those produced from pristine casein (contact angle $93.8^{\circ}$ versus $23.6^{\circ}$ ), a good color developing ability, and an improved thermal stability. The authors reported that CACPL based NPs presented a performance as a leather finishing agent comparable and even better than commercially available products. Finally, the composite showed a preferable biodegradability, making it a promising material for coating applications.

In other work, Ma et al. ${ }^{84}$ synthesized CA-CPL/acrylate NPs by using random amphiphilic copolymers as emulsifier. The copolymerization of acrylic monomers and CA-CPL was initiated by APS, while a random amphiphilic copolymer, including VAC, AM, and BA blocks, was used as emulsifier. The PC was in the range $30-55 \%$. A scheme of the synthesis route can be seen in Figure 3. The presence of the amphiphilic copolymer helped the formation of micelles swollen with monomer. This hybrid latex has the potential to be an economic and green product as waterborne printing ink binder, leather finishing agent, and coating, among others, due to its biodegradability and excellent performance.

$\mathrm{Ma}$ et al. ${ }^{72}$ have also employed the EF-EP with APS as initiator to synthesize hybrid NPs composed by CA-CPL and a synthetic copolymer including BA, MMA, and poly(dimethylsiloxane) (PDMS). The NPs had a mean diameter of $50 \mathrm{~nm}$ with a narrow distribution. During film-formation, a porous structure was developed due to the migration of organic silicone to the coating-air surface (microphase separation). As a result, films with an enhanced water vapor and gas permeation were formed. Moreover, the films showed surface hydrophobicity, biodegradability, and good filmforming properties, being in this way an attractive alternative material with potential to be used in textiles and in the food packaging industry.

$\mathrm{Xu}$ et al. ${ }^{103}$ synthesized CA-CPL/acrylate/silica latex via double-in situ EP. In this proposal, a condensation reaction occurs between a silane coupling agent $(\mathrm{KH} 750)$ and a silica precursor (tetraethoxysilane) in the outer region of CA-CPL particles, which were useful to facilitate the emulsification of the acrylate monomers. After the addition of the initiator (APS), a free radical polymerization takes place between silane coupling agent and casein, and between acrylate and casein, resulting in a core-shell structure (mean diameter $80 \mathrm{~nm}$ ) with an inorganic silica shell and an organic CA-CPL/acrylate core. The hybrid films formed from this latex showed higher hydrophobicity, lower water absorption, superior tensile strength, and reduced flexibility when compared with the protein/acrylate films without silica.

Hollow CA-CPL/acrylate NPs were prepared by Zhang et al. ${ }^{104}$ in a two-step process involving (i) the EP of CA-CPL in the presence of the monomers MMA, BA, and methyl acrylic acid (MAA) initiated by APS; and (ii) the subsequent alkali swelling process in which a migration of the hydrophilic chains in the core of the NPs was produced. The resultant hollow NPs, with a mean diameter of $156 \mathrm{~nm}$, have been tested for opaque coating applications, resulting in tunable transmission between $97 \%$ and $57 \%$. Moreover, the coatings exhibited 
excellent antiultraviolet behavior, with almost $0 \%$ transmittance below 200-300 nm light wavelength.

The use of functionalized casein in the hybrid NPs synthesis has shown to be an effective tool to increase the amount of protein in latex formulations, allowing for a better exploitation of this biopolymer resource. A summary of the total amount of casein, casein type, and monomers used in some of the mentioned works is presented in Table 2.

Whey Protein. Whey proteins, mainly obtained as a byproduct of cheese production, ${ }^{62}$ represent $\sim 20 \%$ of milk proteins. These proteins are a group of globular proteins, which consist primarily of $\beta$-lactoglobulin and $\alpha$-lactalbumin. Other components are immunoglobulins, bovine serum albumin (BSA), lactoferrin, and lactoperoxidase. They can be classified as whey protein concentrate (WPC) or whey protein isolate (WPI), for which the protein content of WPC ranges from 25 to $90 \%$, and for WPI is higher than $90 \% .{ }^{54,70}$ Whey ingredients contain all 20 essential amino acids that the human body requires, being in this way an excellent product to increase the nutritional value of foods. ${ }^{105,106}$ Because of this, the main applications of this protein family are found in the food industry. The global production of whey protein was around 240 million tonnes in 2014, with a value of USD 5.4 billion. $^{106}$

As a byproduct of cheese manufacture, whey protein was considered a polluting effluent from the dairy industry, and discarded in rivers or lands without any treatment. ${ }^{105}$ It is an important environmental problem due to its high production volume and organic content, making necessary the expansion of its industrial exploitation, and opening the possibility to introduce whey protein in a second step of the chain values and to produce more eco-friendly materials.

Whey protein is water-soluble-up to $40 \%$ by weight-and it is known to be capable of forming elastic films, which have a good oxygen barrier and moderate moisture permeability. ${ }^{107}$ Beyond the food industry, other current applications include environmentally safe adhesives ${ }^{62,108}$ (unlike casein, the use of whey protein for adhesives is relatively new), ${ }^{62,109}$ biodegradable coatings, ${ }^{45,110}$ drug delivery and gene-therapy, ${ }^{49,50,111,112}$ and edible films ${ }^{113-115}$ among others. ${ }^{7,116,117}$ However, due to its hydrophilicity, whey protein-based materials exhibit poor mechanical and water-vapor barrier properties. ${ }^{107}$ The research done in whey protein/synthetic polymer hybrid NPs with an orientation to industrial applications is scarce. However, new tools have been developed which can be useful for its future implementation in obtaining of this type of NPs.

One example of these tools is presented in the work by Chan et al., ${ }^{118}$ in which polymerizable whey protein was prepared through an amine-based reaction with methacrylic anhydride to introduce (meth)acrylamide moieties onto the protein backbone. Methacrylic anhydride is produced as a byproduct of the amine-anhydride reaction, and its presence did not degrade the mechanical properties of the final product, so purification steps may be avoided. In this work reactive whey protein was obtained, which allows an improved control over chemical cross-linking density in a subsequent free-radical polymerization step. Despite the aim of this research being the synthesis of protein-based thermoset elastomers, the reported method to obtain polymerizable whey protein can be a helpful tool to efficiently develop new hybrid NPs via free radical EP, in much the same way as the use of HMC, where the degree of compatibility with the synthetic polymer is controlled by the presence of methacrylic groups.
Sharma and Luzinov ${ }^{119}$ produced bioplastics by blending WPI with natural rubber latex (mainly composed of cys-1,4polyisoprene), and WPI with egg white albumin. They found that the addition of about $10 \%$ of any of these biopolymers to the protein improved the composite toughness without compromising the whey protein strength and stiffness. The compatibilization between the protein and rubber/egg white albumin has not been proven in this work. However, the authors suggest that compatibilized latex of natural rubber particles and WPI may have been obtained by the reaction between amino acids groups in both materials.

Gao et al. ${ }^{120}$ developed an eco-friendly adhesive of the family of aqueous polymer solution-isocyanate (API) adhesives, which are primarily composed of a water based glue and an isocyanate cross-linking agent. In this case, the adhesive formulation included a polyvinyl acetate (PVAc) latex, a solution of thermal denatured whey protein, and a methylene diphenyl diisocyanate (MDI) as cross-linking agent $(\mathrm{PC}=$ $230 \%$ ). Despite a latex characterization not being performed, it is assumed that core-shell NPs were formed by blending of the PVAc (core) and the denatured protein (shell). Then, these NPs were cross-linked by the reaction of MDI with the amino and carboxyl groups of the protein. Another explored synthesis route in this work consisted of the addition of poly(vinyl alcohol) (PVA) (3-18 wt \%) during the denaturation process of the protein, which resulted in an increased bond durability of the adhesive, due to the interactions between PVA and WPI. It is assumed, as other authors suggested, ${ }^{121,122}$ that PVA was physically cross-linked with the protein via hydrogen bonding, thus leading to compatibilized NPs. Moreover, the effect of time and temperature variations of the denaturation process was studied. Generally, it was found that the unfolding of the protein globular structure induced by the denaturation process improved the bonding strength of the adhesive. Also, the addition of nanoscale $\mathrm{CaCO}_{3}$ powder further increased the bonding strength and durability of the whey protein based API adhesive. Similar strategies varying the plasticizer and crosslinking agent species were presented in a patent of the same authors. ${ }^{123}$

Soy Protein. Soy protein is a relatively inexpensive protein, generated as a byproduct of the soy oil industry. This protein is commercially available in three kinds of products: (i) soy flour (SF), composed by $50 \%$ of proteins and carbohydrates; (ii) soy protein concentrate (SPC), composed by $70 \%$ of protein and nonwater-soluble carbohydrates; and (iii) soy protein isolate (SPI), having a protein content of ca. $90 \%$. Approximately $90 \%$ of soy proteins are storage proteins, mainly globulins, ${ }^{133}$ with an abundance of essential amino acids, whereby they have been used mostly in the food industry. In addition, soy protein contains an important proportion of amino acids with polar and reactive groups such as lysine (6.8\%), arginine (7.7\%), histidine (3.3\%), and cysteine $(2.4 \%),{ }^{134}$ which make the protein suitable for chemical modifications.

Pure soy protein materials are rigid, brittle, with low thermal stability, poor resistance to moisture absorption and water immersion, and highly susceptible to microbial attack. Therefore, many efforts have been made to improve their mechanical and thermal properties, and moisture resistance. In this context, physical and chemical modifications of soy protein have been widely investigated, including $\mathrm{pH}$ adjustment, thermal treatments, incorporation of plasticizers, cross-linking 
reactions, and production of composites by blending with synthetic polymers, which have been extensively reviewed. $^{135-140}$ Also, strategies of chemical modification by grafting with synthetic polymers were reported. ${ }^{141}$

Some of these grafting modifications involve the radical polymerization in aqueous dispersion of hydrophobic vinyl monomers, such as MMA, styrene (St), ethyl acrylate, ethyl methacrylate, BMA, hexyl methacrylate, and acrylonitrile $(\mathrm{AN})$, in the presence of the soy protein. ${ }^{142-149}$ In general, high PC were used ranging from 50 to $500 \%$, and different initiators such as persulfates, redox systems (ascorbic acid/ KPS), and ammonium cerium nitrate were employed. Although none of these works showed NPs characterization, it can be deduced from the synthetic procedure that hybrid latexes were probably obtained. Instead of the latex application, the grafted copolymer was isolated by solvent extraction and used as either hybrid thermoplastics ${ }^{144,146,149}$ or in the formulation of composites. ${ }^{145,148}$ In general, a GSP between 15 and 80 was obtained depending on different polymerization parameters such as $\mathrm{pH}$, temperature, polymerization time, and monomer and initiator concentrations, which affected the grafting extent.

In a simple approach to incorporate soy protein to synthetic latex, some works explored the physical mixing of both materials. ${ }^{150-152}$ However, nonuniform latexes can lead to heterogeneous films, due to the phase segregation of materials, affecting the application properties. Therefore, a synthetic procedure that promotes the formation of grafted copolymer is desirable to make both phases compatible.

Also, the synthesis of waterborne soy protein-based NPs with an orientation to industrial applications was investigated employing scalable methods such as EP and MEP. Kisku and Swain ${ }^{124}$ studied the synthesis of soy protein/PMMA latexes by EF-EP of MMA employing a low content of soy protein (PC ranging from 1 to $5 \%$ as emulsifier) and KPS/ammonium ferrous sulfate as radical initiator. The materials obtained after latexes precipitation and drying showed a uniformed distribution of soy protein. These PMMA/soy protein films exhibited reduced oxygen permeability with better flameretardant properties than pure PMMA films. In addition, hybrid materials showed high biodegradation in activated sludge water, with a weight loss of about $65 \%$ for the material with the highest PC. Similarly, Liu et al. ${ }^{125}$ reported the use of EP for synthesizing St based latexes in the presence of a high content of SPI (PC ranging from 200 to 2000\%) with low solid content ( 5 to $7 \%$ ) and KPS as initiator. Sodium dodecane sulfonate (SDS) was also incorporated into the emulsion recipe in order to improve the emulsifier capability of this protein. Ionic surfactants, such as SDS, denature the soy protein by disrupting the hydrophobic and electrostatic interaction, resulting in a partially unfolded protein structure. The EP with high content of SPI generated very small latex particles, with diameters between 10 and $30 \mathrm{~nm}$, and coreshell morphology. Figure 4 schematizes the formation of coreshell NPs where soy protein is physically linked to the poly $(\mathrm{St})$ core by the interactions with the SDS molecules. This SPIbased thermoplastic showed good mechanical properties and importantly improved water resistance.

In all these articles, the formation of grafted copolymer between soy protein and the synthetic polymer was not evaluated. However, it is presumed that some grafting could have happened during these polymerizations, for which persulfates were used as initiators. ${ }^{144,145}$

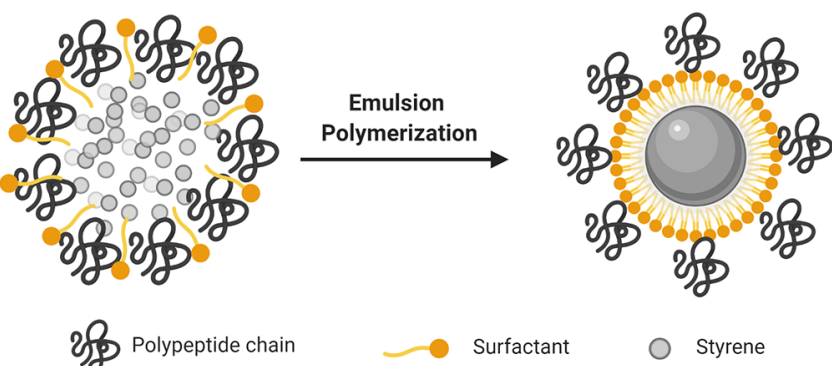

Figure 4. Schematic model of the core-shell structure of soy protein/ poly(St) NPs. ${ }^{125}$

Zheng et al. ${ }^{130}$ have produced an ambient temperaturecurable wood adhesive based on a latex of $\mathrm{SF} / \operatorname{poly}(\mathrm{St})$ synthesized by EP and a polymeric methylenediphenyl diisocyanate as cross-linking agent. SF was previously exposed to a combination of enzymatic and acid treatments to hydrolyze the carbohydrates and to denature the protein, followed by a chemical modification with $N$-methylolacrylamide. Functional groups of soy protein, such as carboxylic acids, react with the $-\mathrm{OH}$ of $\mathrm{N}$-methylolacrylamide producing a polymerizable protein that promotes the graft copolymerization with the St during the EP. The concentration of St was varied from 2 to $10 \%$ (based on the weight of modified SF) giving a PC between 535 to $2674 \%$. The EP was carried out at $75{ }^{\circ} \mathrm{C}$ in two consecutive steps: (i) a batch polymerization containing all the modified SF and 1/4 of the mixture of St and initiator (APS), during $20 \mathrm{~min}$; and (ii) a semibatch polymerization dosing the rest of St and initiator during $4 \mathrm{~h}$. In this form, latex with a final solid content between 20 and $25 \%$ was produced. The formation of SF/poly $(\mathrm{St})$ grafted copolymer was qualitatively confirmed by FTIR but without quantifying the degree of grafting. These hybrid latexes were mixed with a polymeric methylenediphenyl diisocyanate that reacted with hydrophilic groups of the SF and the $-\mathrm{OH}$ in the wood, producing a cross-linking adhesive at ambient temperature, with improved water resistance and thermal stability.

Recently, the synthesis of acrylic/SPI hybrid latexes by emulsion copolymerization of acrylic monomers (MMA, BA, and 2-(methacryloyloxy)ethyl acetoacetate), was reported in order to produce waterborne wood coatings. ${ }^{153}$ Latex with variable content of SPI (PC $=1.7-11.4 \%)$ and with theoretical solid content between 27 and $29 \%$ was produced. Soy protein was previously treated by heating in $\mathrm{NaOH}$ solution, followed by the addition of sodium metabisulfite to break the secondary and quaternary structures of the protein. The latex synthesis involved a first semibatch EP of acrylic monomers, using a mixture of sodium dodecyl sulfate and alkylphenolpolyoxyethylene ether (OP-10) as surfactants; followed by a second polymerization stage with the addition of the modified soy protein solution, after the monomer feeding was completed. The unreacted monomer, at the moment in which soy protein was added, took part in the formation of grafted soy protein/ acrylic copolymer, giving a higher GSP (ranging from 1.1 to 7.5) with the increase of soy protein concentration. The average diameter of hybrid NPs was in the range $35-56 \mathrm{~nm}$, which is lower than the NPs diameter of analogous latex without soy protein $(60 \mathrm{~nm})$ possibly indicating the formation of a secondary particle population. The application properties of these hybrid latexes as wood adhesive (wear resistance, adhesion, gloss, and pencil hardness) improved with the protein concentration. The same trend was observed for the 
mechanical properties, except for the hybrid material with the highest PC (11.7\%) that was very brittle.

The MEP method was also used to synthesize soy protein/ acrylic NPs by copolymerization of BA and MMA, in order to produced wood adhesives. ${ }^{126}$ Soy protein with a previous denaturalization process, by heating in a $\mathrm{NaOH}$ solution, or neat soy protein (without denaturalization treatment) was incorporated with a mix of alkylphenol ethoxylates and sodium lauryl sulfate (SLS) as surfactant. This synthetic strategy allowed the production of latex with high solid content, around $37 \%$, but with a relatively low concentration of soy protein (PC $=1.2-6.2 \%$ ). Films obtained from latexes synthesized with neat soy protein showed protein segregation, while an improved phase compatibility and homogeneity resulted when denaturalized soy protein was used. In addition, close mechanical performance to commercial wood adhesives, such as melamine-urea-formaldehyde and phenol-formaldehyde resins, were obtained, with the important environmental advantage of avoiding the formaldehyde emission.

Another synthetic strategy to produce soy protein hybrid NPs was reported by Bhattacharjee and Bong, ${ }^{127}$ using reversible addition-fragmentation chain transfer (RAFT) polymerization. In this work, soy protein hydrolyzates-based graft copolymers with poly(AM) and poly(AA) - which form NPs when dispersed in an aqueous medium-were produced. To obtain the grafted copolymers, benzylthiocarbonate moieties were incorporated on the protein surface by acylation of free amino groups with $\mathrm{N}$-ydroxysuccinimide (NHS), creating a protein macrochain transfer agent. Then, RAFT polymerization was carried out in dimethyl sulfoxide (DMSO) with $2,2^{\prime}$-azobis (2-methylpropionitrile) (AIBN) as initiator, and using two concentrations of the protein macrochain transfer agent, 10 and 50\%. It was hypothesized that the NP formation by dispersing grafted copolymers in aqueous medium was driven by protein/protein aggregation. In this form, NPs with average diameters between 66 and $162 \mathrm{~nm}$ were obtained depending on the composition of grafted copolymers.

Patents also reported the industrial application of soy protein/synthetic polymers NPs. Riley and Coco ${ }^{128}$ described the production of soy protein/synthetic polymer latexes with a high solid content $(30-43 \%)$ for their use as a binder in paper coating formulation. Hybrid latexes were synthesized by EF$\mathrm{EP}$ of diene monomers (e.g., 1,3 butadiene, isoprene) and vinyl monomers (e.g., St, alpha methyl styrene) in the presence of soy protein ( $\mathrm{PC}=11-43 \%)$, using oil soluble azo initiators (e.g., 2,2'-azobisisobutyronitrile) and a chain transfer agent (e.g., tert-dodecyl mercaptan). Also, soy protein/acrylic hybrid NPs were fabricated and used as replacement for conventional inorganic pigments, commonly employed in paper coating formulations. ${ }^{129}$ The hybrid NPs are formed by the EF-EP process of a monomer-or mixture of monomers-such as St or MMA, and variable concentration of carboxylated SPI (PC $=4-60 \%)$. The preferred initiators are azo nitriles. Semibatch polymerization strategies were used, feeding a pre-emulsion of monomers and soy protein. The particle size control was governed by the protein level contained in the pre-emulsion. In this way, final average particle diameters of the obtained hybrid latexes ranged from 90 to $600 \mathrm{~nm}$, the bigger particles being synthesized at lower concentration of protein. The use of these hybrid latexes in combination with an inorganic pigment in paper coating formulations improved gloss and ink holdout, as compared to a coating in which the pigment composition consisted only of an inorganic material. Moreover, an improved water resistance, water holding, and a potential for reduction in the coating sticking during the paper finishing process were obtained as compared to conventional inorganic polymeric pigments. It is worth noting that the patented method was also successful employing casein instead of soy protein. Moreover, latex containing SPI were produced by the EP of VAC and dioctyl maleate in order to obtain adhesives. ${ }^{154}$ Depending on the adhesive application, soy protein was added during polymerization, after polymerization, or both. However, the concentration of protein incorporated during the polymerization was low, around 1\%, and other emulsifiers (anionic emulsifiers based on soybean oil) were used to obtain stable latex.

Collagen. Collagen is the most abundant animal-protein. It provides the principal body-structural and mechanical support. ${ }^{155}$ There are 20 genetically distinct members of the collagen family. The majority are fibril forming collagens: type I (tendon, skin, and bone), type II (cartilage), and type III (vasculature and skin). These collagen types are found forming fibrillar structures, which are an essential part of tissue structure. ${ }^{156-159}$ Collagen is a highly cross-linked material which is usually insoluble in water and many solvents. The molecule is formed by three chains held together in a triplehelical structure by multiple physical interactions. ${ }^{160-162}$ The temperature of thermal denaturation of collagen depends on the $\mathrm{pH}$ of the environmental medium, water content, and degree of cross-linking. Hydrolyzed collagen (HC) is a collection of peptides with low molecular weight (between 3 and $6 \mathrm{kDa}$ ) that can be obtained by enzymatic, acid, or alkaline hydrolysis. HC can be extracted from different sources such as porcine or bovine. HC properties such as molecular weight of the peptide chain, functional activity, and solubility are affected by the type and source of extraction. ${ }^{61}$ Moreover, gelatin is obtained by partial acid/alkaline hydrolysis or by thermal or enzymatic degradation of collagen. Gelatin molecules consist of repeating sequences of proline, alanine, and glycine amino acids, which are responsible for the triple helical structure of gelatin. The unique triple helix structure, consisting of three polypeptide chains, is responsible for the high stability of gelatin. ${ }^{163}$

According to a new research report by Global Market Insights Inc., the global collagen market is anticipated to exceed USD 6 billion by 2026 . $^{164}$ The major contributors to the rising demand for gelatin and $\mathrm{HC}$ are the food, cosmetic, and beverage industries, due to the gelling capacity (texturizing, gel formation, water binding capacities and thickening) as well as the surface covering (foam formation and stabilization, emulsion, adhesion and cohesion, film forming capacity and protective colloid function), and hydration properties (solubility and swelling) of these materials. ${ }^{165,166}$

Different blends ${ }^{167-174}$ and hydrogels ${ }^{175-177}$ involving collagen derivatives with synthetic polymers were reported, but only a few methods have been informed on the production of hybrid NPs. One of the first reports about the synthesis of hybrid NPs was the work by Ramaraj et al., ${ }^{178}$ which presented the preparation of collagen based composite by blending a latex of poly(MMA-co-n-BA) with different contents of gelatin. The cross-linking effect of glutaraldehyde on gelatin and diallylphthalate on MMA-co-n-BA polymer was investigated, reporting a higher film tensile strength for those fully crosslinked composites. Also, the gelatin content of the film 
composite improved the tensile strength. Deselnicu et al. ${ }^{174}$ studied the rheology of blends of vinyl-acrylic copolymer latexes and $\mathrm{HC}$ aqueous solutions, which is of interest in the acquisition of biomaterials in industry, agriculture, and cosmetics among others. Moreover, Ye et al. ${ }^{179}$ reported the synthesis of core-shell NPs composed by $\mathrm{AgTiO}_{2}$ (core) and PMMA with grafting of the HC (shell). The NPs were synthesized by graft polymerization and water-in-oil EP.

The EF-EP proposed by $\mathrm{Li}$ et al., ${ }^{79}$ previously addressed, was also employed to produce collagen/PMMA hybrid NPs. Following this strategy, Luque et al. ${ }^{31}$ recently reported the synthesis of hybrid collagen/acrylic NPs by EF-EP of AA and BA with varied $\mathrm{HC}$ content (from 15 to $50 \%$ ) and $\mathrm{H}_{2} \mathrm{O}_{2}$ as hydroperoxide initiator. Despite the amount of collagen incorporated being significant, with this method just a small fraction could be grafted, with a GP of approximately 10\%. In this case they demonstrated that EF-EP resulted in an adequate technique for synthesizing stable collagen/acrylic latexes with particle size exceeding $500 \mathrm{~nm}$. The obtained latexes presented excellent film formation capability, giving place to materials with different mechanical and adhesive properties, depending on the percentage of collagen, neutralization degree, and moisture content. ${ }^{131}$ This characteristic opens the opportunity to obtain switchable biobased materials, where the adhesion is controlled by their moisture content.

On the other hand, Zhang et al. ${ }^{180}$ synthesized AA/gelatin core-shell NPs via template polymerization, in which occurs the simultaneous polymerization of $\mathrm{AA}$ and gelatin. At the reaction conditions $(\mathrm{pH}=2)$ the poly(acrylic acid) is insoluble, allowing the formation of NPs. In this case, the system APS $/ N, N, N^{\prime}, N^{\prime}$-tetraethylmethylene diamine was used as initiator, while a selective cross-linking of the shell protein was produced with glutaraldehyde in order to lock the NPs structure. Despite the obtained solid content of the latex being very low $(3 \%)$, the resultant cross-linked PAA/gelatin NPs were $\mathrm{pH}$-responsive and the gelatin shell made the NPs good candidates to be employed in bioapplications.

Gelatin has been employed to produce hybrid NPs for photographic coating applications. ${ }^{181-183}$ The synthesis method involved obtaining polymeric latex by EP having NP diameters between 30 and $500 \mathrm{~nm}$ and a further blending with gelatin solutions having low content of $\mathrm{Ca}$ ions. ${ }^{182}$ Moreover, compatibilized hybrid gelatin/polymer NPs were also achieved, for which covalent bonding between the amine or sulfhydryl groups of gelatin and the carbonyl groups of the polymer was attained through the use of carbamoylonium salts. ${ }^{181}$ On the other hand, the EP of hydrophobic monomers in the presence of gelatin (protein content up to $30 \%$ ) was also employed in aqueous photographic coating compositions. ${ }^{183}$

Zein. Zein is the major prolamin of corn and encompasses $50 \%$ of the total protein of endosperm. ${ }^{184}$ Zein is a heterogeneous mixture of polypeptides classified into four fractions named $\delta$-, $\gamma$-, $\beta$-, and $\alpha$-zein $(70-85 \%$ of total zein) based on their amino acid sequences, molecular weight, solubility, and charge. ${ }^{60}$ From 2010, commercial zein was produced as a byproduct from corn gluten meal by two main companies, Flo Chemical Corp. (Ashburnham, MA) and Showa Sangyo (Tokyo, Japan). Then, zein as a byproduct of the ethanol process was introduced to the market by Prairie Gold, Inc. (Bloomington, IL). ${ }^{60}$ Nowadays, commercial zein is mostly $\alpha$-zein with a molecular weight between 19 and $22 \mathrm{kDa}$, and its composition may vary according to the acquisition method. ${ }^{60,185}$
Compared to other plant-based proteins, zein has significant and unique properties due to its amino acid sequence, which is mainly composed by nonpolar and uncharged amino acids as glutamine $(21-26 \%)$, leucine $(20 \%)$, proline $(10 \%)$, and alanine $(10 \%) .{ }^{186}$ Possibly due to this structure, zein is relatively heat- and $\mathrm{pH}$-stable, and water insoluble, but soluble in aqueous ethanol. Although this protein has both hydrophobic and hydrophilic side domains in its structure, it is frequently considered to be a hydrophobic protein due to its insolubility in water. ${ }^{185,187}$

Since zein is not an indispensable protein for human consumption due to its poor water solubility and low nutritional value (it lacks in the essential amino acids as lysine and tryptophan $)^{60}$ and it is obtained as a byproduct of wellestablished processes, this biopolymer has attracted many industries to explore its potential as a feedstock material. In addition, the attention given to zein-based polymers is primarily attributed to their ability to form films, biocompatibility, biodegradability, and ability to encapsulate both hydrophobic and hydrophilic actives. Moreover, zein was approved as a generally recognized as safe (GRAS) material by the United States Food and Drug Administration. ${ }^{186,188,189}$ As a result, reports on zein-based biomaterials for cosmetic, biodegradable plastics, coatings, tissue engineering, biomedical applications, and control drug delivery applications have appeared, with zein being in different formats such as fibers, micelles, nanoparticles, nanospheres, or films, where zein is applied pure, in physical mixtures with other materials or as part of a hybrid material. ${ }^{52,184,186,190-199}$ However, much less has been done with the incorporation of zein in the synthesis of hybrid NPs with synthetic monomers. One exception is the work by Allasia et al., ${ }^{132}$ where a dispersion of hybrid acrylic/ zein/casein NPs with average diameter of $209 \mathrm{~nm}$ and a solid content of $35 \%$ were obtained through emulsifier-free MEP. The proposed synthesis strategy involved the use of the stabilization power of casein to form stable miniemulsion droplets, which contain both acrylic monomers (BA and MMA) and zein. Two kinds of initiators were employed in order to have thermal initiation with KPS and the redox $\mathrm{TBHP} / \mathrm{NH}_{2}$-casein radical formation. ${ }^{79}$ The hybrid material had a total PC of $25 \%$, in which only $5 \%$ of that protein was zein. Despite the low concentration of hydrophobic protein, the hybrid material showed improved water resistance (2.4 times less of water absorption) and a more hydrophobic surface (contact angle $83^{\circ}$ ) compared with zein-free hybrid material (Figure 5), due to the high compatibility achieved between the different phases (GP $=75 \%$ ). In addition, these hybrid materials were partially biodegradable in compost, losing $15 \%$ of their initial weight after 14 days of being buried.

On the other hand, zein based particles could be formed by stabilizing it with different biomaterials using the antisolvent method. Biomaterials such as tea polysaccharide (TPS), ${ }^{200}$ pectin, ${ }^{201}$ carboxymethylated short-chain amylose (CSA), ${ }^{202}$ alginate, ${ }^{203}$ sodium caseinate (SC), ${ }^{204-208}$ carboxymethyl chitosan (CMCS), ${ }^{190}$ chitosan, $^{209,210}$ starch, $^{211}$ and tannic acid $^{212}$ act as electrostatic and steric stabilizer for zein-based particles, offering a good challenge for obtaining fully biobased NPs with excellent final properties based on the synergy of the combined biopolymers. A summary of these hybrid NPs, including the biomaterials used, composition, size, particle yield (ratio of NPs produced to initial biomaterial amount), and its applications are presented in Table 3. As can be seen, it is possible to synthesize various NPs based on zein, having 


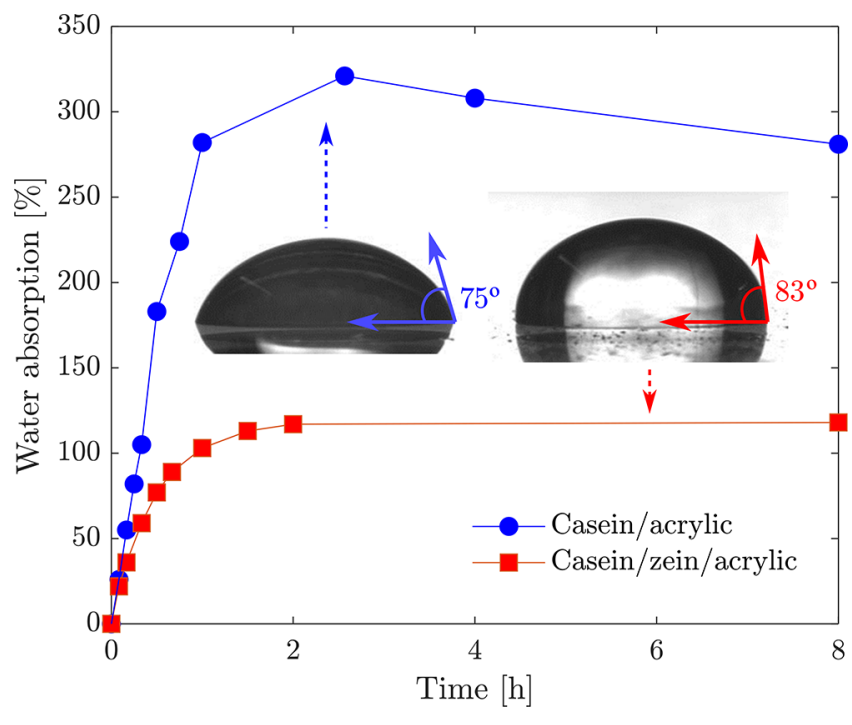

Figure 5. Water absorption of hybrid casein based film with and without zein and static contact angles of water onto its surfaces. The contact angle of film obtained from casein/zein/acrylic hybrid NPs is $83^{\circ}$, close to that of pristine acrylic film.

different diameters and different zein/biomaterial ratios with high particle yields (70-90\%). Figure 6 shows image examples of the morphology of the hybrid NPs of zein-SC, zein-CMCS, and zein/tannic acid. In addition, some research has focused on the development of a procedure that can be scalable and economically attractive for the industry to obtain stable NPs using some variants of the antisolvent precipitation method, as flash nano precipitation (FNP), ${ }^{213}$ new four-stream FNP configuration, ${ }^{189}$ dual channel microfluidization method, ${ }^{214}$ and the combination of FNP with spray-drying as fabrication scalable processes. ${ }^{215}$ Although most of the applications of the aforementioned NPs are aimed at control drug delivery systems (Table 3), these zein based NPs could be employed


Figure 6. Examples of the morphology of some zein/biomaterial hybrid NPs. (a) TEM image of zein/SC NPs. Reprinted in part with permission from ref 205. Copyright 2017 Dovepress. (b) SEM images of VD3 encapsulated zein-CMCS NPs complex with calcium. Reprinted from ref 190. Copyright 2012 American Chemical Society. (c) Field emission scanning electron microscopy image of zein/tannic acid (1:0.2). Reprinted from ref 212. Copyright 2015 American Chemical Society.

as precursors for the formation of new protein/synthetic polymer hybrid NPs, paving the way for the use of this biomaterial in other industrial applications.

Other Proteins. A few more examples of hybrid protein/ polymer NPs-or available tools for their developmentemploying other less common proteins are given in this section. For each case a brief description of the protein, the method of synthesis of the hybrid NPs, and the NPs application is presented. An interesting method for the development of protein/polymer NPs is given in the work by Xue et al., ${ }^{216}$ in which hybrid NPs including BSA were synthesized and used to stabilize water-in-water $(\mathrm{w} / \mathrm{w})$ emulsions. Albumins are a family of water-soluble proteins which can be found in egg, milk, and blood. This protein contains many ionizable groups, which makes albumin one of the most soluble plasma proteins. ${ }^{217}$ It has found many applications in medicine, food industry, and in research studies as a protein model. Emulsions are interesting systems for the synthesis of functional materials, and in particular $\mathrm{w} / \mathrm{w}$ emulsions are attractive for an eco-friendly process, because the use of organic solvents is avoided. However, the

Table 3. Summary of Zein Based NPs Synthesized Using Some Variants of the Antisolvent Precipitation Method

\begin{tabular}{|c|c|c|c|c|c|}
\hline system & $\begin{array}{l}\text { zein } / X^{a} \\
\text { ratio }\end{array}$ & $\begin{array}{l}\text { particle yield } \\
(\%)\end{array}$ & size $(\mathrm{nm})$ & applications & ref \\
\hline zein/TPS & $\begin{array}{l}1: 0.07 \\
-1: 0.7\end{array}$ & $20-70$ & $130-495$ & anticancer drug delivery system & 200 \\
\hline zein/pectin & $1: 0.32$ & $>92$ & 250 & controlled release of dietary supplements & 201 \\
\hline zein/CSA & $1: 2-1: 13$ & nonspecified & $140-200$ & oral drug delivery & 202 \\
\hline zein/alginate & $1: 0.25$ & 95 & 160 & nanodelivery systems for bioactive molecules & 203 \\
\hline \multirow[t]{4}{*}{ Zein/SC } & $1: 1$ & nonspecified & $110-500$ & $\begin{array}{l}\text { encapsulation and/or controlled release of therapeutic drugs, bioactive components, } \\
\text { and food pigments }\end{array}$ & $205^{\dagger}$ \\
\hline & $1: 1-5: 1$ & nonspecified & $100-130$ & & 206 \\
\hline & $1: 0.1-1: 2$ & nonspecified & $120-150$ & & 204 \\
\hline & $\begin{array}{l}1: 0.75 \\
-1: 1.25\end{array}$ & $74-82$ & $177-240$ & & 207 \\
\hline zein/CMCS & $1: 0.5-1: 2$ & nonspecified & $86-200$ & encapsulation and controlled release of fat-soluble vitamin & $190^{\frac{\xi}{5}}$ \\
\hline \multirow[t]{2}{*}{ zein/chitosan } & $\begin{array}{l}1: 0.05 \\
-1: 0.2\end{array}$ & nonspecified & $211-862$ & controlled release of bioactive agent & 209 \\
\hline & $\begin{array}{l}1: 0.02 \\
-1: 0.1\end{array}$ & nonspecified & $60-1000$ & pickering emulsion stabilizer & 210 \\
\hline $\begin{array}{l}\text { zein/SC with PDC- } \\
\text { CA }\end{array}$ & $\begin{array}{l}1: 0.25 \\
-1: 0.8\end{array}$ & nonspecified & $141-421$ & oral drug delivery & 208 \\
\hline zein/starch & $1: 2-1: 10$ & nonspecified & $115-564$ & pickering emulsion stabilizer & 211 \\
\hline zein/tannic acid & $1: 0.1-1: 0.5$ & nonspecified & $96-250$ & pickering emulsion stabilizer & $212^{\|}$ \\
\hline
\end{tabular}

${ }^{a} \mathrm{X}$ represents the biomaterial used to produce the zein-based particles. Corresponding NPs morphologies are shown in ${ }^{\dagger}$ Figure $6 \mathrm{a}$, ${ }^{\dot{*}} 6 \mathrm{~b}$, and ${ }^{\|} 6 \mathrm{c}$, respectively. 




Figure 7. Scheme of the main routes involved for producing hybrid protein-synthetic polymer NPs; EF-EP of the protein in the presence of a monomer or mix of monomers, using persulfates or hydro peroxides as polymerization initiators. The main stages of the process are initiation (a), propagation in water phase (b), and NPs nucleation (c).

stabilization of w/w emulsions is not straightforward due to the low tension of water-water interfaces and the associated large interfacial thickness. Xue et al., ${ }^{216}$ have demonstrated that methoxy polyethylene glycol (mPEG)/BSA NPs have the ability to stabilize $\mathrm{w} / \mathrm{w}$ emulsions. In their work, mPEG/ protein conjugate was achieved by reacting BSA protein with mPEG-acetaldehyde via Schiff base chemistry at a $\mathrm{pH}$ near to the protein IEP. Moreover, they showed that the NPs diameter $(200-500 \mathrm{~nm})$ can be easily tuned with the reaction time.

A method to fabricate core-shell particles, where the shell is made of an albumin and the core is a water-insoluble material, was reported in a patent by Jaromir and Atkins. ${ }^{218}$ The method consists in dispersing a water-immiscible material in an aqueous solution of a coagulable protein, such as egg albumin or blood albumin, to form a particles dispersion. The following step involves the coagulation of the protein onto the surface of the particles as a result of an increase in the temperature of the particles. The rise in temperature is achieved by the previous incorporation of carbon black infrared absorbers in the waterimmiscible material, and a further exposure to infrared radiation for a certain time. The size of the core-shell particles is set by the size of the water-immiscible particle (liquid or solid) in the oil-in-water emulsion. This method was proposed a priori as a useful tool to encapsulate materials, but depending on the employed materials it could be suitable for other ends.

Another interesting combination of an animal-derived protein with other materials (such as synthetic polymers and inorganic compounds) is given by silk protein-based composite materials. Silk proteins are mainly obtained from the silkworm specie Bombyx mori, and from spiders such as the Araneus diadematus or Nephila clavipes. Silk protein materials have been used for applications such as papers, strings, textiles, and tissues due to the excellent mechanical properties and good biocompatibility of silk. ${ }^{219}$ Because these materials are acquired naturally, their application at the industrial scale has not been achieved. However, spider silk-like proteins can be produced using recombinant DNA technology. ${ }^{220}$ Hybrid particles composed of Bombyx mori fibroin and poly(acrylonitrile-co-methyl acrylate) have been obtained in the work by Sun et al. ${ }^{21}$ These particles were simply formed by 


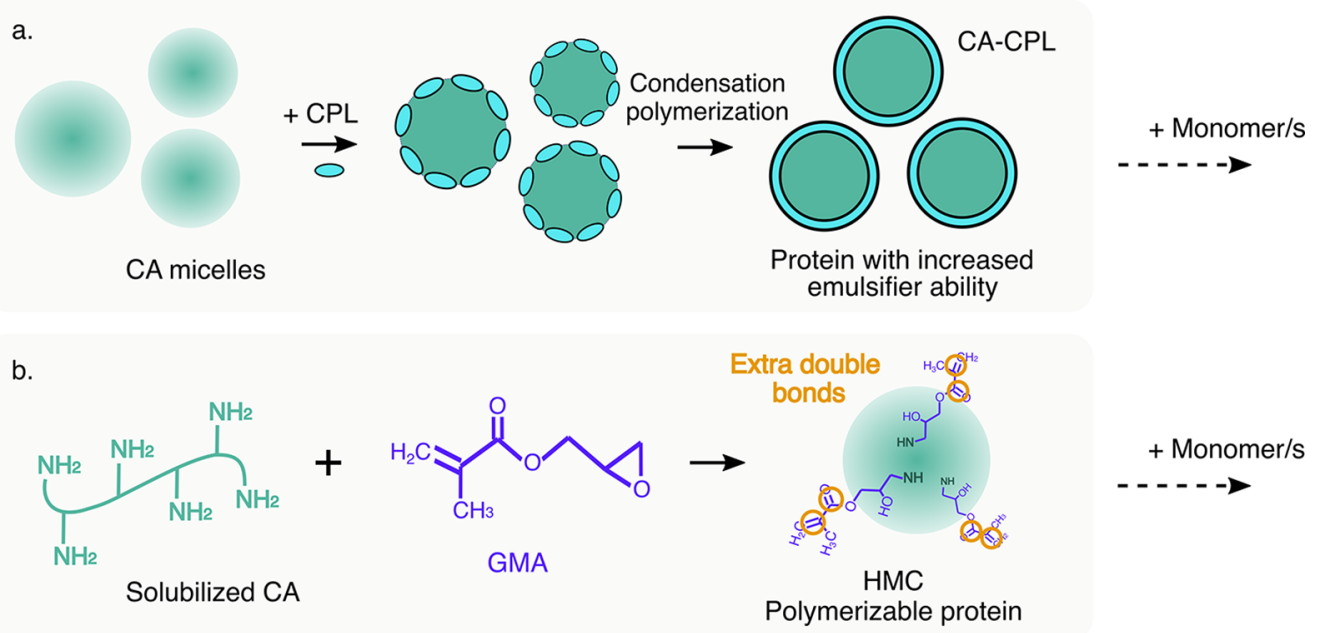

Figure 8. Scheme of CA modification strategies previously to EP process. Route employed for obtaining casein with an increased emulsifier capability through its reaction with CPL (a), ${ }^{67,72,84}$ and HMC by the glycidyl ether reaction of CA (b)..$^{82,132}$

blending both components, establishing hydrogen bonds between the protein and the polymer particles.

Synthesis of Hybrid Protein Based NPs. The main applications of the hybrid latexes were film forming material, coatings, adhesives, leather finishing agents, pigments, and textile. A summary of the synthesis method, PC, mean diameter, and applications of the NPs are summarized in Table 2. The EP process has been the main route to obtain hybrid protein/synthetic polymer latexes. Most of the proposed strategies involve a free-emulsifier mechanism, in which the amphiphilic character of proteins or the grafted molecule formed with the synthetic polymer self-assemble to form the precursors of core-shell compatibilized particles in an EP. Also, an important improvement in the performance of hybrid latex is reached when compatibilization between the protein and synthetic polymer is enhanced by protein modification previous to the EP. In this direction, this session summarizes the main features of EF-EP, involving hybrid NP formation (Figure 7), and the more efficient and scalable protein modification proposals (Figure 8 ).

The EP process includes a monomer-in-water emulsion leading, with the addition of a radical initiator, to a dispersion of colloidal polymer particles (latex). Several mechanisms have been proposed to explain the formation of particles during EP. Among them, the homogeneous nucleation mechanism was able to explain the EP of water-soluble monomers. ${ }^{222,223}$ It involves the formation of oligoradicals by the interaction of a radical initiator and the monomer in the aqueous phase, which become insoluble and form particle precursors by precipitation. On the other hand, in the micellar (or heterogeneous) nucleation the radicals diffuse into monomer swollen micelles where the polymerization occur. ${ }^{222,223}$ For a given polymerization system, the determination of the nucleation mechanism is not straightforward since it is a function of several characteristics, including the monomers, initiator, emulsifier, temperature, and kinetics parameters among others. Moreover, the EP process is highly complex because it involves multiple steps on different time and length scales. A detailed description of the method and proposed nucleation mechanisms can be found in the literature. ${ }^{1,222-224}$

In this scenario, most of the approaches for obtaining protein based NPs by EF-EP included in this review involve the particle formation mechanisms summarized in Figure 7. In all the cases, EF-EP proceeds with the protein soluble in the water phase (or its water-soluble fraction), containing different functional and reactive groups, which depend on its origin and/or its previous chemical modification. As schematized in Figure 7 different pathways of particle formation can be found, which are governed by the employed protein, that is, its hydrophilic/hydrophobic balance (capability to form micelles), concentration, and its chemical modification, as well as the type of initiation system. The use of persulfate initiators, such as APS and KPS, produces sulfate radicals' ions which could easily abstract labile hydrogen from protein functional groups and form radical sites onto the protein backbone. Also, the interaction between persulfate and carboxylate in the aqueous phase forming radical carboxyl species is well accepted. ${ }^{225}$ These radical species on protein backbone could initiate the polymerization of the available monomer in the water phase, leading to the grafting between the protein and the synthetic polymer (Figure $7 \mathrm{~b}$, left). The amphiphilic protein/polymer chains then self-assemble to form compatibilized core-shell NPs (Figure 7c, left). The presence of sulfate radical anions may also lead to the aqueous phase polymerization of the water-soluble monomers, until being absorbed into the protein micelles swollen with the monomers or its precipitation followed by the stabilization with ungrafted protein (Figure $7 \mathrm{~b}, \mathrm{c}$, middle). These two alternatives promote the formation of noncompatibilized NPs. The nucleation of noncompatibilized NPs was not proven for the case of persulfates initiators, since the amount of grafted and ungrafted polymer and protein was not experimentally assessed. ${ }^{24}$

On the other hand, when hydroperoxides or peroxides $(\mathrm{ROOH})$ are employed as initiators, a redox pair between the protein and the $\mathrm{ROOH}$ specie is created (Figure 7, right). Li et al. ${ }^{79}$ proposed this method in which amino radicals in the protein backbone and alkyl radicals are formed. At the temperature at which the reaction was explored, the $\mathrm{ROOH}$ initiator does not thermally decompose, and therefore it reacts mainly with the amino groups of the protein generating a nitrogen centered radical and an alkoxy radical (RO.). Then, the amino radicals promoted the graft copolymerization of vinyl monomers in the water phase by forming the grafted copolymer protein/synthetic polymer which acts as a macro- 
surfactant in the self-assembling of the microdomains (Figure $7 \mathrm{~b}, \mathrm{c}$, right). Monomer polymerization takes place inside the hydrophobic microdomains to form amphiphilic core-shell NPs. On the other hand, the homopolymerization of the monomer initiated by the alkoxy radicals is also present during the process. This is related to a second method of nucleation in which the formation of noncompatibilized particles occurs by hydrophobic radicals' coagulation or absorption into the protein micelles, as identified by Picchio et al. ${ }^{24}$ for the synthesis of casein/acrylate latexes (Figure $7 c$, middle).

When $\mathrm{Cu}(\mathrm{III})$ and $\mathrm{Ni}(\mathrm{IV})$ are used as initiators ${ }^{97,98}$ a similar situation to the propagation and nucleation stages of the hydroperoxides route is developed. The metals induce the formation of radicals in the protein backbone, creating sites of grafting and polymerization of the synthetic monomers. Then, the formation of compatibilized NPs is promoted in a subsequent stage of particle nucleation.

As it could be observed in Figure 7, it was found that the incorporation of water-soluble initiators (persulfates and alkylhydroperoxides) in an EF-EP and in the presence of a protein could promote one or another of these two competitive mechanisms, which can be favored by tuning the protein concentration, as it was identified by Picchio et al. ${ }^{24}$ In the cases where the protein concentration is low, grafting extent is high and the biomaterial availability is limited for micelles formation or stabilization of noncompatibilized NPs. Consequently, the predominant way of progress of the polymerization is the compatibilized particles, resulting in highly compatibilized hybrid latexes. In contrast, when the protein concentration is high, formation of noncompatibilized NPs is promoted by the available ungrafted protein, which acts as a macro-emulsifier. Although it has been not appropriately addressed, these nucleation pathways are expected to also occur when supernormal valence transitional metals are used as initiators. Thus, the development of protein chemical modification strategies to improve compatibility of proteinbased hybrid NPs with high biomaterial content is highly desirable for reducing the products carbon footprint and a better exploitation of renewable resources.

In this direction, two principal strategies were identified. The first one consisted in increasing the emulsifying capability of the protein in order to create stable micelles which serve as a substrate for a subsequent monomer polymerization inside them, as schematized in Figure 8a. This route was followed by $\mathrm{Ma}$ and co-workers ${ }^{67,72,84}$ in the EF-EP of casein in the presence of VAC, acrylate monomers, and PDMS. This protein modification approach consisted in the condensation polymerization between CPL and the carboxyl and amine groups of casein, through the ring opening of the CPL molecules. The incorporated pendant groups in the casein backbone acted as blockers of the polar groups of the protein increasing its emulsifier capability, resulting in more stable casein micelles. In this way, CA-CPL micelles acted as self-emulsifier and as substrate for the polymerization of the hydrophobic monomers.

Another approach to increase the grafting efficiency between protein and synthetic polymer consisted in adding vinyl functionalities to the protein, which then serve as propagating sites in a radical polymerization. With this aim Picchio et al. ${ }^{101}$ synthesized functionalized casein through the reaction of protein with AA, in the presence of $\mathrm{N}$-(3-dimethylaminopropyl)- $N^{\prime}$-ethylcarbodiimine hydrochloride (EDC). In this way, an amide bond is formed between the casein and the $\mathrm{AA},{ }^{226}$ providing new acrylic functionality able to propagate via radical polymerization. This modified casein improved the compatibilization degree of hybrid NPs obtained by EP of acrylic monomers. However, significantly enhanced results were obtained in the latter work by Picchio and co-workers ${ }^{82,102}$ where HMC was used in the EF-EP in the presence of MMA and BA. HMC was prepared through a glycidyl ether reaction to incorporate pendant methacrylic groups onto the protein backbone (Figure $8 \mathrm{~b}$ ). These pendant groups and the primary amino groups serve as propagation sites during the polymerization, favoring the formation of compatibilized hybrid NPs following the mechanisms summarized in Figure 7. Also, Zheng et al. ${ }^{130}$ proposed the vinyl functionality incorporation to soy protein using $N$-methylolacrylamide as functional agent. A possible esterification reaction between carboxylic acid of the protein and hydroxyl groups of $\mathrm{N}$-methylolacrylamide was proposed.

Although EF-EP was the main polymerization strategy employed for obtaining protein based hybrid NPs, also a few proposals employed MEP. ${ }^{227}$ Fapeng et al. ${ }^{126}$ used MEP to obtain soy protein/acrylic NPs, which were then used to fabricate wood adhesive films. Neat and modified soy proteins were used, where the latter case increased the compatibility with the polymer and the films homogeneity. The emulsifiers employed to stabilize the miniemulsion were alkylphenol ethoxylates and SLS. N-Hexadecane was employed as cosurfactant, and the polymerization reaction was initiated by using APS. This approach also involved the modification of soy protein by the denaturation of the protein in aqueous solution of sodium hydroxide at $70{ }^{\circ} \mathrm{C}$. The modified protein showed an increased surface energy due to the rise of unsaturated bonds, which provided more reaction sites able to be combined with the acrylate monomers in the posterior MEP process.

Another example of the use of MEP was given by Allasia et al., ${ }^{132}$ where a emulsifier-free latex of acrylic/zein/casein NPs having a high solids content (35\%) was obtained. The use of neat and methacrylated casein was tested as stabilizer, instead of emulsifier, resulting in hybrid latexes with improved compatibility and water resistance.

\section{SUMMARY AND PERSPECTIVES}

Waterborne polymeric NPs are nowadays a widespread product for obtaining high-quality materials at large scale. However, despite their many advantages, polymeric NPs are still mainly produced from petroleum-based monomers. The continuous demand for this resource, the reserves of which are of exhaustible nature is nonsustainable, and for this reason the exploration of renewable feedstocks to prepare a new generation of waterborne NPs with low carbon footprint and environmental impact is imperative for both academics and industries. In this context, this review collects the works done to obtain hybrid protein/polymer NPs, which have been employed or have the potential to be used in industrial applications. The incorporation of proteins in the waterborne NPs formulation puts latex technology at a higher level, offering the possibility to improve its structural, functional, and biodegradability features. In that sense, hybrid protein-based latexes have been used to produce and study final products, including coatings, ${ }^{82,84,100,128,129,132}$ adhesives, ${ }^{120,126,131}$ and films, ${ }^{6,72,124}$ which have shown improved properties in comparison with the synthetic polymer latexes (without 
protein). Moreover, properties comparable to existent commercial products were obtained in some cases. ${ }^{67,102,126}$

The main synthesis route for obtaining these protein/ synthetic polymer latexes involves the emulsion polymerization in the absence of emulsifier, ${ }^{24,67,79,99,124}$ which paves the way for its industrial implementation without significant technological upgrades. The efforts made have allowed the achievement of producing high solids hybrid latexes with elevated protein content ${ }^{82,83,99,132,153}$ and compatibility, 82,132 highly desirable for an efficient exploitation of this sustainable resource. These features were in most cases the result of a prepolymerization stage of protein modification, which pursues introducing extra active sites onto the protein backbone to promote its grafting with the synthetic polymer ${ }^{82,132}$ or to modify its hydrophilic-hydrophobic balance. ${ }^{67,72,84}$ In this scenario, highly compatibilized hybrid materials showed superior properties than the simple constituents' addition, demonstrating a synergetic contribution of both components due to the intimate contact between phases. Some of these synergetic improvements observed in the applications of protein-based hybrid NPs were partial biodegradability, $^{66,67,72,84,124,132}$ thermal stability, ${ }^{67}$ film formation with low requirement of formulation agents (better NPs coalescence) ${ }^{24,131}$ solvent resistance, ${ }^{24}$ water resistance, $^{72,82,102,103,125}$ and mechanical strength ${ }^{103,125,126,153}$ among others.

The most explored incorporated protein was casein, and hence the more advanced reported developments were with this protein. ${ }^{6,67,102,104}$ This is because casein is a commonly employed reagent in the formulation of many industrial products, due to its excellent film-forming features, and therefore it is highly available in large volume and with acceptable purity. There are many protein alternatives which, though less explored, offer the opportunity to incorporate additional functionalities into waterborne hybrid latexes and put many biomaterials obtained as byproducts of other industries into a second step of the chain values. In this regard, it is remarkable the few efforts for incorporating whey protein, which is obtained from a polluting effluent, to formulate biobased products such as bioplastics and coatings. ${ }^{119,120}$

One drawback reported for many protein-based hybrid products was their low resistance to waterborne solvents, because most of these biomaterials are hydrophilic. Many attempts focused on solving this limitation involved the chemical modification of the protein to improve its compatibility with the synthetic phase. One unexplored alternative was the formulation of cross-linkable hybrid latexes, which is a commonly used strategy in the coating and adhesive industry for obtaining high-performance products. ${ }^{228,229}$ It is expected that the incorporation of functionalities into proteinbased hybrid NPs that promote cross-linking during filmforming, that is, a biobased self-cross-linkable latex, could open the opportunity to increase their biocomponent content and reach improved features for producing high-performance alternative materials.

One important point arising from the composition of protein-based hybrid latexes is that the explored systems considered the incorporation of only one protein. An exception is the work by Allasia et al., ${ }^{132}$ in which the synergetic balance between a hydrophilic and a hydrophobic protein with acrylicbased NPs was proposed. The incorporation of a low fraction of zein counteracted the hydrophilic character of casein, by reaching a film surface hydrophobicity similar to that of pure acrylics. Under this context, a material design involving an accurate combination of proteins, or otherwise a protein with other biomaterials, may provide the opportunity to produce novel waterborne hybrid latexes with high biocontent and an end-use performance governed by the synergetic joining of their functional components. Following this basis, many authors have investigated the formation of zein-based particles stabilized with different biopolymers. ${ }^{189,190,194,200-213,230,231}$ Although these zein-based NPs offer a good challenge for obtaining fully biobased materials, this strategy could be exploited as precursors for producing a new generation of proteins/synthetic polymer hybrid NPs in many industrial applications.

Finally, although most of the proposed strategies pursue reducing the employment of oil-based materials by incorporating an industrially available protein, few articles focused on investigating the involved mechanism of hybrid particles nucleation, ${ }^{24,79}$ the effect of protein interaction on the polymerization process and its kinetics, ${ }^{95}$ and the influence of protein content on the end-use materials and their final properties. ${ }^{24,65,95,125,127,129,131}$ It is expected that advances on the fundamental knowledge about the interplay of protein with synthetic polymer will contribute to rationalize the design of both the waterborne hybrid NPs and the synthetic pathway. In this regard, future research should aim to expand the assortment of proteins explored up to now, encompassing those which are of great interest in biological catalysis and other technological applications.

\section{AUTHOR INFORMATION}

\section{Corresponding Authors}

Roque J. Minari - Polymer Reaction Engineering Group, INTEC, Santa Fe S3000, Argentina; Facultad de Ingeniería Química, Universidad Nacional del Litoral, Santa Fe, Santa Fe S3000, Argentina; 이이이.org/0000-0003-3645-5317; Email: rjminari@santafe-conicet.gov.ar

Luis M. Gugliotta - Polymer Reaction Engineering Group, INTEC, Santa Fe S3000, Argentina; Facultad de Ingeniería Química, Universidad Nacional del Litoral, Santa Fe, Santa Fe S3000, Argentina; Email: lgug@intec.unl.edu.ar

\section{Authors}

Luisa G. Cencha - Polymer Reaction Engineering Group, INTEC, Santa Fe S3000, Argentina; Facultad de Ingeniería y Ciencias Hídricas, Universidad Nacional del Litoral, Santa $\mathrm{Fe}$, Santa Fe S3000, Argentina; 이이.org/0000-00032858-6827

Mariana Allasia - Polymer Reaction Engineering Group, INTEC, Santa Fe S3000, Argentina

Ludmila I. Ronco - Polymer Reaction Engineering Group, INTEC, Santa Fe S3000, Argentina; Facultad de Ingeniería Química, Universidad Nacional del Litoral, Santa Fe, Santa Fe S3000, Argentina; 이이이.org/0000-0001-6954-3159

Gisela C. Luque - Polymer Reaction Engineering Group, INTEC, Santa Fe S3000, Argentina; Facultad de Ingeniería Química, Universidad Nacional del Litoral, Santa Fe, Santa Fe S3000, Argentina

Matías L. Picchio - Departamento de Química Orgánica, Facultad de Ciencias Químicas, Universidad Nacional de Córdoba, IPQA-CONICET, Córdoba, Córdoba X5000, Argentina; 10 orcid.org/0000-0003-3454-5992

Complete contact information is available at: 
https://pubs.acs.org/10.1021/acs.iecr.0c05958

\section{Notes}

The authors declare no competing financial interest.

\section{ACKNOWLEDGMENTS}

The author acknowledge the financial support received from CONICET, UNL (CAI+D 50420150100100LI), and ANPCyT (PICT-2016-3876) (all of Argentina).

\section{REFERENCES}

(1) Chern, C. S. Emulsion Polymerization Mechanisms and Kinetics. Prog. Polym. Sci. 2006, 31, 443-486.

(2) Ramli, R. A.; Laftah, W. A.; Hashim, S. Core-shell polymers: a review. RSC Adv. 2013, 3, 15543.

(3) Overbeek, A.; Bückmann, F.; Martin, E.; Steenwinkel, P.; Annable, T. New Generation Decorative Paint Technology. Prog. Org. Coat. 2003, 48, 125-139.

(4) Goldschmidt, A.; Streitberger, H.-J. In BASF Handbook on Basics of Coating Technology; Andrew, W., Ed.; American Coatings Literature; Vincentz Network, 2003.

(5) Chou, C.-S.; Weier, J. E. In Polymer Dispersions and Their Industrial Applications; Urban, D., Takamura, K., Eds.; John Wiley \& Sons, Ltd, 2002; Chapter 14, pp 355-382.

(6) Rodrigo, A. B. Development of Waterborne Polymeric Dispersions Based on Biobased Monomers for Their Application as PSAs and Coatings. Ph.D. Thesis, University of the Basque Country UPV/EHU, 2020.

(7) Polymer Dispersion Market - Global Industry Analysis, Size, Share, Growth, Trends, and Forecast 2019 - 2027; Report Linker, 2020.

(8) Harris, S.; Staffas, L.; Rydberg, T.; Eriksson, E. Renewable Materials in the Circular Economy; IVL Swedish Environmental Research Institute Ltd, 2018.

(9) Molina-Gutiérrez, S.; Ladmiral, V.; Bongiovanni, R.; Caillol, S.; Lacroix-Desmazes, P. Radical Polymerization of Biobased Monomers in Aqueous Dispersed Media. Green Chem. 2019, 21, 36-53.

(10) Goikoetxea, M.; Minari, R. J.; Beristain, I.; Paulis, M.; Barandiaran, M. J.; Asua, J. M. Polymerization Kinetics and Microstructure of Waterborne Acrylic/Alkyd Nanocomposites Synthesized by Miniemulsion. J. Polym. Sci., Part A: Polym. Chem. 2009, 47, 4871.

(11) Lim, K.; Ching, Y.; Gan, S. Effect of Palm Oil Bio-Based Plasticizer on the Morphological, Thermal and Mechanical Properties of Poly(Vinyl Chloride). Polymers 2015, 7, 2031-2043.

(12) Fei, G.; Sun, L.; Wang, H.; Gohar, F.; Ma, Y.; Kang, Y.-M. Rational design of phosphorylated poly(vinyl alcohol) grafted polyaniline for waterborne bio-based alkyd nanocomposites with high performance. Prog. Org. Coat. 2020, 140, 105484.

(13) Pathan, S.; Ahmad, S. Synergistic Effects of Linseed Oil Based Waterborne Alkyd and 3-Isocynatopropyl Triethoxysilane: Highly Transparent, Mechanically Robust, Thermally Stable, Hydrophobic, Anticorrosive Coatings. ACS Sustainable Chem. Eng. 2016, 4, 30623075.

(14) Smeets, N. M.; Imbrogno, S.; Bloembergen, S. Carbohydrate functionalized hybrid latex particles. Carbohydr. Polym. 2017, 173, $233-252$.

(15) Shamshina, J. L.; Berton, P.; Rogers, R. D. Advances in Functional Chitin Materials: A Review. ACS Sustainable Chem. Eng. 2019, 7, 6444-6457.

(16) Mastalygina, E.; Varyan, I.; Kolesnikova, N.; Gonzalez, M. I. C.; Popov, A. Effect of Natural Rubber in Polyethylene Composites on Morphology, Mechanical Properties and Biodegradability. Polymers 2020, 12, 437.

(17) Capezza, A. J.; Newson, W. R.; Olsson, R. T.; Hedenqvist, M. S.; Johansson, E. Advances in the Use of Protein-Based Materials: Toward Sustainable Naturally Sourced Absorbent Materials. ACS Sustainable Chem. Eng. 2019, 7, 4532-4547.
(18) Rajinipriya, M.; Nagalakshmaiah, M.; Robert, M.; Elkoun, S. Importance of Agricultural and Industrial Waste in the Field of Nanocellulose and Recent Industrial Developments of Wood Based Nanocellulose: A Review. ACS Sustainable Chem. Eng. 2018, 6, 28072828.

(19) Thakur, V. K.; Thakur, M. K.; Raghavan, P.; Kessler, M. R. Progress in Green Polymer Composites from Lignin for Multifunctional Applications: A Review. ACS Sustainable Chem. Eng. 2014, 2, 1072-1092.

(20) Isikgor, F. H.; Becer, C. R. Lignocellulosic biomass: a sustainable platform for the production of bio-based chemicals and polymers. Polym. Chem. 2015, 6, 4497-4559.

(21) Guilbert, S.; Cuq, B. 11. Material formed from proteins; De Gruyter: Berlin, Boston, 2020; pp 299-338.

(22) Zhang, L.; Zeng, M. Monomers, Polymers and Composites from Renewable Resources; Elsevier, 2008; pp 479-493.

(23) Shi, K.; Huang, Y.; Yu, H.; Lee, T.-C.; Huang, Q. Reducing the Brittleness of Zein Films through Chemical Modification. J. Agric. Food Chem. 2011, 59, 56-61.

(24) Picchio, M. L.; Minari, R. J.; Gonzalez, V. D. G.; Passeggi, M. C.; Vega, J. R.; Barandiaran, M. J.; Gugliotta, L. M. Waterborne Acrylic-Casein Nanoparticles. Nucleation and Grafting. Macromol. Symp. 2014, 344, 76-85.

(25) Lai, M.; Cai, K.; Zhao, L.; Chen, X.; Hou, Y.; Yang, Z. Surface Functionalization of TiO2Nanotubes with Bone Morphogenetic Protein 2 and Its Synergistic Effect on the Differentiation of Mesenchymal Stem Cells. Biomacromolecules 2011, 12, 1097-1105.

(26) Qi, H.; Zheng, W.; Zhang, C.; Zhou, X.; Zhang, L. Novel Mussel-Inspired Universal Surface Functionalization Strategy: Protein-Based Coating with Residue-Specific Post-Translational Modification in Vivo. ACS Appl. Mater. Interfaces 2019, 11, 12846-12853.

(27) Liu, R.; Zhao, J.; Han, Q.; Hu, X.; Wang, D.; Zhang, X.; Yang, P. One-Step Assembly of a Biomimetic Biopolymer Coating for Particle Surface Engineering. Adv. Mater. 2018, 30, 1802851.

(28) Silvernail, L. H.; Bain, W. M. Synthetic and Protein Adhesives for Paper Coating; TAPPI monograph series, no. 22; Technical Association of the Pulp and Paper Industry. Coating Committee., 1961.

(29) Kickelbick, G. Hybrid Materials: Synthesis, Characterization, and Applications; John Wiley \& Sons, 2021.

(30) Johnson, R. P.; John, J. V.; Kim, I. Recent developments in polymer-block-polypeptide and protein-polymer bioconjugate hybrid materials. Eur. Polym. J. 2013, 49, 2925-2948.

(31) Gupta, P.; Nayak, K. K. Characteristics of protein-based biopolymer and its application. Polym. Eng. Sci. 2015, 55, 485-498.

(32) Saif, B.; Zhang, W.; Zhang, X.; Gu, Q.; Yang, P. Sn-Triggered Two-Dimensional Fast Protein Assembly with Emergent Functions. ACS Nano 2019, 13, 7736-7749.

(33) Qin, R.; Liu, Y.; Tao, F.; Li, C.; Cao, W.; Yang, P. ProteinBound Freestanding 2D Metal Film for Stealth Information Transmission. Adv. Mater. 2018, 1803377.

(34) Wang, L.; Deng, L.; Liu, Y.-N. Protein-Metal-Ion Networks: A Unique Approach toward Metal Sulfide Nanoparticles Embedded In Situ in Nanocomposites. Chem. - Eur. J. 2019, 25, 904-912.

(35) Palomo, J. M. Nanobiohybrids: a new concept for metal nanoparticles synthesis. Chem. Commun. 2019, 55, 9583-9589.

(36) Chawla, S. S.; Gorakshakar, A. C.; Ghosh, K. K.; Madkaikar, M. R.; Devarajan, P. V. Fabrication of gelatin functionalized silver nanoparticles for blood group profiling. Nanotechnology 2020, 31, 295102.

(37) Sothornvit, R.; Rhim, J.-W.; Hong, S.-I. Effect of nano-clay type on the physical and antimicrobial properties of whey protein isolate/ clay composite films. J. Food Eng. 2009, 91, 468-473.

(38) Swain, S. K.; Priyadarshini, P. P.; Patra, S. K. Soy Protein/Clay Bionanocomposites as Ideal Packaging Materials. Polym.-Plast. Technol. Eng. 2012, 51, 1282-1287.

(39) Kiryukhin, M. V.; Lau, H. H.; Lim, S. H.; Salgado, G.; Fan, C.; Ng, Y. Z.; Leavesley, D. I.; Upton, Z. Arrays of Biocompatible and 
Mechanically Robust Microchambers Made of Protein-PolyphenolClay Multilayer Films. ACS Biomater. Sci. Eng. 2020, 6, 5653-5661.

(40) Kaseem, M.; Ko, Y. G. A novel hybrid composite composed of albumin, WO3, and $\mathrm{LDHs}$ film for smart corrosion protection of $\mathrm{Mg}$ alloy. Composites, Part B 2021, 204, 108490.

(41) Ravi, S. K.; Tan, S. C. Solar Energy Harvesting with Photosynthetic Pigment-Protein Complexes; Springer: Singapore, 2020; pp 65-77.

(42) Corrado, I.; Abdalrazeq, M.; Pezzella, C.; Girolamo, R. D.; Porta, R.; Sannia, G.; Giosafatto, C. V. L. Design and characterization of poly (3-hydroxybutyrate-co-hydroxyhexanoate) nanoparticles and their grafting in whey protein-based nanocomposites. Food Hydrocolloids 2021, 110, 106167.

(43) Peng, J.; Calabrese, V.; Ainis, W. N.; Scager, R.; Velikov, K. P.; Venema, P.; van der Linden, E. Mixed gels from whey protein isolate and cellulose microfibrils. Int. J. Biol. Macromol. 2019, 124, 10941105.

(44) Saveleva, M. S.; Eftekhari, K.; Abalymov, A.; Douglas, T. E. L.; Volodkin, D.; Parakhonskiy, B. V.; Skirtach, A. G. Hierarchy of Hybrid Materials-The Place of Inorganics-in-Organics in it, Their Composition and Applications. Front. Chem. 2019, 7, 179.

(45) Motelica, L.; Ficai, D.; Ficai, A.; Oprea, O. C.; Kaya, D. A.; Andronescu, E. Biodegradable Antimicrobial Food Packaging: Trends and Perspectives. Foods 2020, 9, 1438.

(46) Palivan, C. G.; Fischer-Onaca, O.; Delcea, M.; Itel, F.; Meier, W. Protein-polymer nanoreactors for medical applications. Chem. Soc. Rev. 2012, 41, 2800-2823.

(47) Wu, Y.; Ng, D. Y. W.; Kuan, S. L.; Weil, T. Protein-polymer therapeutics: a macromolecular perspective. Biomater. Sci. 2015, 3, 214-230.

(48) Boyer, C.; Huang, X.; Whittaker, M. R.; Bulmus, V.; Davis, T. P. An overview of protein-polymer particles. Soft Matter 2011, 7, $1599-1614$.

(49) Ha, H.-K.; Rankin, S.; Lee, M.-R.; Lee, W.-J. Development and Characterization of Whey Protein-Based Nano-Delivery Systems: A Review. Molecules 2019, 24, 3254.

(50) Saallah, S.; Lenggoro, I. W. Nanoparticles Carrying Biological Molecules: Recent Advances and Applications. KONA Powder Part. J. 2018, 35, 89-111.

(51) DeFrates, K.; Markiewicz, T.; Gallo, P.; Rack, A.; Weyhmiller, A.; Jarmusik, B.; Hu, X. Protein Polymer-Based Nanoparticles: Fabrication and Medical Applications. Int. J. Mol. Sci. 2018, 19, 1717.

(52) Martínez-López, A. L.; Pangua, C.; Reboredo, C.; Campión, R.; Morales-Gracia, J.; Irache, J. M. Protein-based nanoparticles for drug delivery purposes. Int. J. Pharm. 2020, 581, 119289.

(53) Sarode, A.; Sawale, P.; Khedkar, C.; Kalyankar, S.; Pawshe, R. Encyclopedia of Food and Health; Elsevier, 2016; pp 676-682.

(54) Dhillon, G. Protein Byproducts: Transformation from Environmental Burden Into Value-Added Products; Elsevier Science, 2016.

(55) Hettiarachchy, N.; Kalapathy, U. Soybeans; Springer, 1997; pp 379-411.

(56) Cook, R. B.; Mallee, F. M.; Shulman, M. L. Purification of zein from corn gluten meal. WO Patent WO1993012667A1, 1993.

(57) Widyasari, R.; Rawdkuen, S. Extraction and characterization of gelatin from chicken feet by acid and ultrasound assisted extraction. FABJ. 2014, 2, 85-97.

(58) Pelegrine, D.; Gasparetto, C. Whey proteins solubility as function of temperature and $\mathrm{pH}$. Food Sci. Technol. 2005, 38, 77-80.

(59) Shukla, R.; Cheryan, M. Zein: the industrial protein from corn. Ind. Crops Prod. 2001, 13, 171-192.

(60) Anderson, T. J.; Lamsal, B. P. REVIEW: Zein Extraction from Corn, Corn Products, and Coproducts and Modifications for Various Applications: A Review. Cereal Chem. 2011, 88, 159-173.

(61) León-López, A.; Morales-Peñaloza, A.; Martínez-Juárez, V. M.; Vargas-Torres, A.; Zeugolis, D. I.; Aguirre-Álvarez, G. Hydrolyzed Collagen-Sources and Applications. Molecules 2019, 24, 4031.

(62) Guo, M.; Wang, G. Milk Protein Polymer and Its Application in Environmentally Safe Adhesives. Polymers 2016, 8, 324.
(63) Global Casein and Caseinate Market to Account for US\$ 3564.4 Mn by 2025. Process Industry Match, https://www.globenewswire. com/news-release/2015/08/14/760737/10146093/en/GlobalCasein-and-Caseinate-Market-will-Reach-US-3564-4-Mn-by-2025Persistence-Market-Research.html (accessed on 2020/11/23).

(64) Wusigale; Liang, L.; Luo, Y. Casein and pectin: Structures, interactions, and applications. Trends Food Sci. Technol. 2020, 97, 391-403.

(65) Ma, J. Z.; Xu, Q. N.; Gao, D. G. Study on Synthesis and Performances of Casein Resin Grafting Modified by Caprolactam/ Acrylic Esters/Vinyl Acetate/Organic Silicone. Adv. Mater. Res. 2010, 123-125, 1267-1270.

(66) Ma, J.; Xu, Q.; Gao, D.; Zhou, J.; Zhang, J. Blend composites of caprolactam-modified casein and waterborne polyurethane for filmforming binder: Miscibility, morphology and properties. Polym. Degrad. Stab. 2012, 97, 1545-1552.

(67) Ma, J.; Xu, Q.; Zhou, J.; Gao, D.; Zhang, J.; Chen, L. Nanoscale core-shell structural casein based coating latex: Synthesis, characterization and its biodegradability. Prog. Org. Coat. 2013, 76, $1346-1355$

(68) Barreto, P.; Pires, A.; Soldi, V. Thermal degradation of edible films based on milk proteins and gelatin in inert atmosphere. Polym. Degrad. Stab. 2003, 79, 147-152.

(69) Sohail, S. S.; Wang, B.; Biswas, M. A. S.; Oh, J.-H. Physical, Morphological, and Barrier Properties of Edible Casein Films with Wax Applications. J. Food Sci. 2006, 71, C255-C259.

(70) Audic, J.-L.; Chaufer, B.; Daufin, G. Non-food applications of milk components and dairy co-products: A review. Lait 2003, 83, 417-438.

(71) Ghosh, A.; Ali, M. A.; Dias, G. J. Effect of Cross-Linking on Microstructure and Physical Performance of Casein Protein. Biomacromolecules 2009, 10, 1681-1688.

(72) Ma, J.; Zhang, F.; Qiao, Y.; Xu, Q.; Zhou, J.; Zhang, J. ViPDMS incorporated with protein-based coatings designed for permeability-enhanced applications. J. Appl. Polym. Sci. 2018, 135, 46501.

(73) Fan, Q.; Ma, J.; Xu, Q.; Zhang, J.; Simion, D.; Carmen, G.; Guo, C. Animal-derived natural products review: Focus on novel modifications and applications. Colloids Surf., B 2015, 128, 181-190.

(74) Narayanan, S.; Pavithran, M.; Viswanath, A.; Narayanan, D.; Mohan, C. C.; Manzoor, K.; Menon, D. Sequentially releasing dualdrug-loaded PLGA-casein core/shell nanomedicine: Design, synthesis, biocompatibility and pharmacokinetics. Acta Biomater. 2014, $10,2112-2124$.

(75) Costa, J. P.; Carvalho, S.; Jesus, S.; Soares, E.; Marques, A. P.; Borges, O. Optimization of Chitosan- $\alpha$-casein Nanoparticles for Improved Gene Delivery: Characterization, Stability, and Transfection Efficiency. AAPS PharmSciTech 2019, 20, 132.

(76) Picchio, M. L.; Cuggino, J. C.; Nagel, G.; Wedepohl, S.; Minari, R. J.; Igarzabal, C. I. A.; Gugliotta, L. M.; Calderón, M. Crosslinked casein-based micelles as a dually responsive drug delivery system. Polym. Chem. 2018, 9, 3499-3510.

(77) Sahba, R.; Seyed, M.; Sajjadi, A. A.; Farhadyar, N.; Sadeghi, B. Preparation and characterization of friendly colloidal Hydroxyapatite based on natural Milk's casein. Int. J. Nanodimens. 2018, 9, 238-245.

(78) Wang, Y.; Ma, J.; Xu, Q.; Zhang, J. Fabrication of antibacterial casein-based $\mathrm{ZnO}$ nanocomposite for flexible coatings. Mater. Des. 2017, 113, 240-245.

(79) Li, P.; Zhu, J.; Sunintaboon, P.; Harris, F. W. New Route to Amphiphilic Core-Shell Polymer Nanospheres: Graft Copolymerization of Methyl Methacrylate from Water-Soluble Polymer Chains Containing Amino Groups. Langmuir 2002, 18, 8641-8646.

(80) Blackley, D. Emulsion Polymerization: Theory and practice; Springer, 1975 .

(81) Picchio, M. L.; Bohórquez, S. J.; van den Berg, P. G. C. A.; Barandiaran, M. J.; Gugliotta, L. M.; Minari, R. J. Waterborne CaseinBased Latexes with High Solids Content and Their High-Throughput Coating Optimization. Ind. Eng. Chem. Res. 2016, 55, 10271-10277. 
(82) Picchio, M. L.; Minari, R. J.; Gugliotta, L. M. Enhancing the coating properties of acrylic/casein latexes with high protein content. J. Coat. Technol. Res. 2017, 14, 543-553.

(83) Aguzin, A.; Jerkovich, J. I.; Trucone, J.; Ronco, L. I.; Minari, R. J.; Gugliotta, L. M. Acrylic-Casein Latexes with Potential Application as Adhesives. Lat. Am. Appl. Res. 2020, 50, 115-120.

(84) Ma, J.; Gan, C.; Xu, Q.; Zhou, J.; Zhang, J. Amphiphilic copolymer stabilized core-shell structural casein-based emulsion. Colloids Surf., A 2015, 471, 65-72.

(85) Ma, J.; Xu, Q.; Zhou, J.; Zhang, J.; Zhang, L.; Tang, H.; Chen, L. Synthesis and biological response of casein-based silica nanocomposite film for drug delivery system. Colloids Surf., B 2013, 111, 257-263.

(86) Mohan, D.; Radhakrishnan, G.; Nagabhushanam, T. Synthesis of casein-g-poly(butyl acrylate). J. Appl. Polym. Sci. 1980, 25, 17991806.

(87) Mohan, D.; Radhakrishnan, G.; Rajadurai, S. Synthesis of Casein-g-Poly(methyl Acrylate). J. Macromol. Sci., Chem. 1983, 20, 201-212.

(88) Mohan, D.; Radhakrishnan, G.; Rajadurai, S. Synthesis of Casein-g-Poly(n-butyl Methacrylate). J. Macromol. Sci., Chem. 1985, $22,75-83$.

(89) Mohan, D.; Radhakrishnan, G.; Rajadurai, S. Synthesis of Casein-g-Poly(Ethyl Acrylate). Leather Sci. 1986, 33, 242.

(90) Mohan, D.; Radhakrishnan, G.; Rajadurai, S.; Rao, K. V.; Cameron, G. G. Graft copolymerization of acrylamide onto casein: A kinetic study. J. Polym. Sci., Part A: Polym. Chem. 1989, 27, 21232133.

(91) Mohan, D.; Radhakrishnan, G.; Rajadurai, S. Synthesis of casein-g-poly(methyl acrylate). II. J. Appl. Polym. Sci. 1990, 39, 15071518.

(92) Somanathan, N.; Sanjeevi, R.; Reddy, C. R.; Radhakrishnan, N. Graft co-polymerization of casein with acrylonitrile and n-butyl methacrylate. Eur. Polym. J. 1987, 23, 489-492.

(93) Dong, Q.; Hsieh, Y.-L. Acrylonitrile graft copolymerization of casein proteins for enhanced solubility and thermal properties. J. Appl. Polym. Sci. 2000, 77, 2543-2551.

(94) Somanathan, N.; Jeevan, R. G.; Sanjeevi, R. Syhthesis of Casein Graft Poly(acrylonitrile). Polym. J. 1993, 25, 939-946.

(95) Li, P.; Liu, J. H.; Wang, Q.; Wu, C. Copper-mediated graft copolymerization of methyl methacrylate onto casein. Macromol. Symp. 2000, 151, 605-610.

(96) Imoto, M.; Ouchi, T. Radical Polymerization of Vinyl Monomers by Hydrophilic Macromolecules. I. Uncatalyzed Polymerization in the Absence of Copper(11) Ions. J. Macromol. Sci., Polym. Rev. 1982, 22, 261-302.

(97) Liu, Y.; Zhang, Y.; Liu, Z.; Deng, K. Graft copolymerization of butyl acrylate onto casein initiated by potassium diperiodatonickelate(IV) in alkaline medium. Eur. Polym. J. 2002, 38, 1619-1625.

(98) Liu, Y.; Li, J.; Yang, L.; Shi, Z. Graft Copolymerization of Methyl Methacrylate onto Casein Initiated by Potassium Ditelluratocuprate(III). J. Macromol. Sci., Part A: Pure Appl.Chem. 2004, 41, 305-316.

(99) Zhu, J.; Li, P. Synthesis and characterization of poly(methyl methacrylate)/casein nanoparticles with a well-defined core-shell structure. J. Polym. Sci., Part A: Polym. Chem. 2003, 41, 3346-3353.

(100) Picchio, M. L.; Passeggi, M. C.; Barandiaran, M. J.; Gugliotta, L. M.; Minari, R. J. Waterborne acrylic-casein latexes as eco-friendly binders for coatings. Prog. Org. Coat. 2015, 88, 8-16.

(101) Picchio, M. L.; Minari, R. J.; Gonzalez, V. D. G.; Barandiaran, M. J.; Gugliotta, L. M. New strategy to improve acrylic/casein compatibilization in waterborne hybrid nanoparticles. J. Appl. Polym. Sci. 2015, 132, 42421 DOI: 10.1002/app.42421.

(102) Picchio, M. L.; Passeggi, M. C.; Barandiaran, M. J.; Gugliotta, L. M.; Minari, R. J. Acrylic/casein latexes with controlled degree of grafting and improved coating performance. Prog. Org. Coat. 2016, 101, 587-596.

(103) Xu, Q.; Ma, J.; Zhou, J.; Wang, Y.; Zhang, J. Bio-based coreshell casein-based silica nano-composite latex by double-in situ polymerization: Synthesis, characterization and mechanism. Chem. Eng. J. 2013, 228, 281-289.

(104) Zhang, F.; Ma, J.; Xu, Q.; Zhou, J.; Simion, D.; Carmen, G.; Wang, J.; Li, Y. Hollow Casein-Based Polymeric Nanospheres for Opaque Coatings. ACS Appl. Mater. Interfaces 2016, 8, 11739-11748.

(105) Ramos, O.; Pereira, R.; Rodrigues, R.; Teixeira, J.; Vicente, A.; Malcata, F. Encyclopedia of Food and Health; Elsevier, 2016; pp 498505.

(106) Global Whey Protein Market - Growth, Trends And Forecast (2015-2020). https://www.prnewswire.com/news-releases/globalwhey-protein-market---growth-trends-and-forecast-2015-2020300155575.html (accessed 2021/01/12).

(107) Gautam, R. B.; Kumar, S. Development of Protein Based Films with Nanoparticle as Strengthening Material for Biodegradable Packaging - A Review. Int. J. Agric. Innov. Res. 2017, 5, 790-805.

(108) Guo, M.; Wang, G. Whey protein polymerisation and its applications in environmentally safe adhesives. Int. J. Dairy Technol. 2016, 69, 481-488.

(109) Tschabold, G. L.; Mueller, D. L. Adhesive from whey and a method of making it. US Patent US2624679A, 1953.

(110) Le Tien, C.; Letendre, M.; Ispas-Szabo, P.; Mateescu, M. A.; Delmas-Patterson, G.; Yu, H.-L.; Lacroix, M. Development of Biodegradable Films from Whey Proteins by Cross-Linking and Entrapment in Cellulose. J. Agric. Food Chem. 2000, 48, 5566-5575.

(111) Khan, A.; Wang, C.; Sun, X.; Killpartrick, A.; Guo, M. Physicochemical and Microstructural Properties of Polymerized Whey Protein Encapsulated 3,30-Diindolylmethane Nanoparticles. Molecules 2019, 24, 702.

(112) Verma, D.; Gulati, N.; Kaul, S.; Mukherjee, S.; Nagaich, U. Protein Based Nanostructures for Drug Delivery. J. Pharm. (Cairo) 2018, 2018, 1-18.

(113) Shendurse, A. M.; Gopikrishna, G.; Patel, A. C.; Pandya, A. J. Milk protein based edible films and coatings-preparation, properties and food applications. J. Nutr. Health Food Eng. 2018, 8, 219-226.

(114) Oymaci, P.; Altinkaya, S. A. Improvement of barrier and mechanical properties of whey protein isolate based food packaging films by incorporation of zein nanoparticles as a novel bionanocomposite. Food Hydrocolloids 2016, 54, 1-9.

(115) Ramos, Ó. L.; Reinas, I.; Silva, S. I.; Fernandes, J. C.; Cerqueira, M. A.; Pereira, R. N.; Vicente, A. A.; Poças, M. F.; Pintado, M. E.; Malcata, F. X. Effect of whey protein purity and glycerol content upon physical properties of edible films manufactured therefrom. Food Hydrocolloids 2013, 30, 110-122.

(116) Han, J. H.; Krochta, J. M. Wetting Properties and Water Vapor Permeability of Whey-Protein-Coated Paper. Trans. ASAE 1999, 42, 1375-1382.

(117) Hidalgo, J.; Jost, R. Kosmetische Oder Therapeutische Zusammensetzung Fuer Topische Anwendung (Cosmetic or therapeutic composition for topical use). DE Patent DE3001300C2, 1988.

(118) Chan, W. Y.; Bochenski, T.; Schmidt, J. E.; Olsen, B. D. Peptide Domains as Reinforcement in Protein-Based Elastomers. ACS Sustainable Chem. Eng. 2017, 5, 8568-8578.

(119) Sharma, S.; Luzinov, I. Whey based binary bioplastics. J. Food Eng. 2013, 119, 404-410.

(120) Gao, Z.; Yu, G.; Bao, Y.; Guo, M. Whey-protein based environmentally friendly wood adhesives. Pigm. Resin Technol. 2011, 40, 42-48.

(121) Srinivasa, P.; Ramesh, M.; Kumar, K.; Tharanathan, R. Properties and sorption studies of chitosan-polyvinyl alcohol blend films. Carbohydr. Polym. 2003, 53, 431-438.

(122) Lacroix, M.; Le, T.; Ouattara, B.; Yu, H.; Letendre, M.; Sabato, S.; Mateescu, M.; Patterson, G. Use of -irradiation to produce films from whey, casein and soya proteins: structure and functionals characteristics. Radiat. Phys. Chem. 2002, 63, 827-832.

(123) Guo, M.; Vayda, M. E.; Gao, Z. Whey-protein based environmentally friendly wood adhesives and methods of producing and using the same. US Patent US20120183794A1, 2012. 
(124) Kisku, S. K.; Swain, S. K. Poly(methyl methacrylate)/soy protein green composites as gas barrier materials. Chin. J. Polym. Sci. 2012, 30, 397-404.

(125) Liu, D.; Tian, H.; Zeng, J.; Chang, P. R. Core-Shell Nanoblends from Soy Protein/Polystyrene by Emulsion Polymerization. Macromol. Mater. Eng. 2008, 293, 714-721.

(126) Fapeng, W.; Jifu, W.; Chunpeng, W.; Fuxiang, C.; Xiaohuan, L.; Jiuyin, P. Fabrication of soybean protein-acrylate composite miniemulsion toward wood adhesive. Eur. J. Wood Wood Prod. 2018, 76, 305-313.

(127) Bhattacharjee, S.; Bong, D. Protein-Polymer Grafts via a Soy Protein Derived Macro-RAFT Chain Transfer Agent. J. Polym. Environ. 2011, 19, 203-208.

(128) Riley, R. R.; Coco, C. E. Grafted soy protein latex. US Patent US4607089A, 1986.

(129) Coco, C. E.; Scacciaferro, L. M. Polymeric Pigments Used in Paper Coating Compositions and a Process for Their Preparation. US Patent US4963604A, 1990.

(130) Zheng, P.; Zeng, Q.; Lin, Q.; Fan, M.; Zhou, J.; Rao, J.; Chen, $\mathrm{N}$. Investigation of an ambient temperature-curable soy-based adhesive for wood composites. Int. J. Adhes. Adhes. 2019, 95, 102429.

(131) Luque, G. C.; Stürtz, R.; Passeggi, M. C.; Gugliotta, L. M.; Gonzalez, V. D.; Minari, R. J. New hybrid acrylic/collagen nanocomposites and their potential use as bio-adhesives. Int. J. Adhes. Adhes. 2020, 100, 102624.

(132) Allasia, M.; Passeggi, M. C. G.; Gugliotta, L. M.; Minari, R. J. Waterborne Hybrid Acrylic/Protein Nanocomposites with Enhanced Hydrophobicity by Incorporating a Water Repelling Protein. Ind. Eng. Chem. Res. 2019, 58, 21070-21079.

(133) Kinsella, J. E. Functional properties of soy proteins. J. Am. Oil Chem. Soc. 1979, 56, 242-258.

(134) Mateos-Aparicio, I.; Cuenca, A. R.; Villanueva-Suárez, M. J.; Zapata-Revilla, M. A. Soybean, a promising health source. Nutr. Hosp. 2008, 23, 305-312.

(135) Song, F.; Tang, D.-L.; Wang, X.-L.; Wang, Y.-Z. Biodegradable Soy Protein Isolate-Based Materials: A Review. Biomacromolecules 2011, 12, 3369-3380.

(136) Deepmala, K. M.; Singh, V. K.; Chauhan, S.; Jain, N. Soy Protein Based Green Composite: A Review. Res. Rev. J. Mater. Sci. 2017, 5, 66-77.

(137) Tian, H.; Guo, G.; Fu, X.; Yao, Y.; Yuan, L.; Xiang, A. Fabrication, properties and applications of soy-protein-based materials: A review. Int. J. Biol. Macromol. 2018, 120, 475-490.

(138) Wang, Z.; Zhao, S.; Pang, H.; Zhang, W.; Zhang, S.; Li, J. Developing Eco-friendly High-Strength Soy Adhesives with Improved Ductility through Multiphase Core-Shell Hyperbranched Polysiloxane. ACS Sustainable Chem. Eng. 2019, 7, 7784-7794.

(139) Rahman, M. M.; Netravali, A. N.; Tiimob, B. J.; Rangari, V. K. Bioderived "Green" Composite from Soy Protein and Eggshell Nanopowder. ACS Sustainable Chem. Eng. 2014, 2, 2329-2337.

(140) Tian, H.; Guo, G.; Xiang, A.; Zhong, W.-H. Intermolecular interactions and microstructure of glycerol-plasticized soy protein materials at molecular and nanometer levels. Polym. Test. 2018, 67, 197-204.

(141) Thakur, M. K.; Thakur, V. K.; Gupta, R. K.; Pappu, A. Synthesis and Applications of Biodegradable Soy Based Graft Copolymers: A Review. ACS Sustainable Chem. Eng. 2016, 4, 1-17.

(142) Xi, D.; Yang, C.; Liu, X.; Chen, M.; Sun, C.; Xu, Y. Graft polymerization of styrene on soy protein isolate. J. Appl. Polym. Sci. 2005, 98, 1457-1461.

(143) Kaith, B. S.; Jindal, R.; Bhatia, J. K. Morphological and thermal evaluation of soy protein concentrate on graft copolymerization with ethylmethacrylate. J. Appl. Polym. Sci. 2011, 120, 2183-2190.

(144) Thakur, V. K.; Thunga, M.; Madbouly, S. A.; Kessler, M. R. PMMA-g-SOY as a sustainable novel dielectric material. RSC Adv. 2014, 4, 18240.

(145) Thakur, V. K.; Kessler, M. R. Synthesis and Characterization of AN-g-SOY for Sustainable Polymer Composites. ACS Sustainable Chem. Eng. 2014, 2, 2454-2460.
(146) Shi, Z.; Reddy, N.; Shen, L.; Hou, X.; Yang, Y. Grafting soyprotein isolates with various methacrylates for thermoplastic applications. Ind. Crops Prod. 2014, 60, 168-176.

(147) Retna, A. M.; Sophia, A.; Theivasanthi, T.; Gopinath, S. C. Performance of Biodegradable Soy-based Polymer and Nanocomposite with Reduced Moisture Absorptivity. Micro Nanosyst. 2018, 10, 40-46.

(148) Thakur, V. K.; Kessler, M. R. Free radical induced graft copolymerization of ethyl acrylate onto Soy for multifunctional materials. Mater. Today Commun. 2014, 1, 34-41.

(149) González, A.; Igarzabal, C. I. A. Study of Graft Copolymerization of Soy Protein-Methyl Methacrylate: Preparation and Characterization of Grafted Films. J. Polym. Environ. 2017, 25, 214-220.

(150) Jong, L. Reinforcement Effect of Soy Protein/Carbohydrate Ratio in Styrene-Butadiene Polymer. J. Elastomers Plast. 2011, 43, 99-117.

(151) Qi, G.; Sun, X. S. Soy Protein Adhesive Blends with Synthetic Latex on Wood Veneer. J. Am. Oil Chem. Soc. 2011, 88, 271-281.

(152) Wang, F.; Wang, J.; Chu, F.; Wang, C.; Jin, C.; Wang, S.; Pang, J. Combinations of soy protein and polyacrylate emulsions as wood adhesives. Int. J. Adhes. Adhes. 2018, 82, 160-165.

(153) Feng, B.; Wang, D.; Li, Y.; Qian, J.; Yu, C.; Wang, M.; Luo, D.; Wei, S. Mechanical Properties of a Soy Protein Isolate-GraftedAcrylate (SGA) Copolymer Used for Wood Coatings. Polymers 2020, 12, 1137.

(154) Browning, J. D.; Vuayendran, B. R. Protein stabilized latex polymer emulsions, method of making, and adhesives containing such emulsions. WO Patent WO2008112644A1, 2008.

(155) Paul, R. G.; Bailey, A. J. Chemical Stabilisation of Collagen as a Biomimetic. Sci. World J. 2003, 3, 138-155.

(156) Nishi, Y.; Doi, m.; Uchiyama, S.; Nishiuchi, Y.; Nakazawa, T.; Ohkubo, T.; Kobayashi, Y. Stabilization mechanism of triple helical structure of collagen molecules. Lett. Pept. Sci. 2003, 10, 533-537.

(157) Orgel, J. P. R. O.; Antonio, J. D. S.; Antipova, O. Molecular and structural mapping of collagen fibril interactions. Connect. Tissue Res. 2011, 52, 2-17.

(158) Usha, R.; Ramasami, T. Structure and conformation of intramolecularly cross-linked collagen. Colloids Surf., B 2005, 41, 2124.

(159) Nakamura, Y. Structure of type I collagen dimers. Int. J. Biol. Macromol. 1987, 9, 281-290.

(160) Goh, K.; Hiller, J.; Haston, J.; Holmes, D.; Kadler, K.; Murdoch, A.; Meakin, J.; Wess, T. Analysis of collagen fibril diameter distribution in connective tissues using small-angle X-ray scattering. Biochim. Biophys. Acta, Gen. Subj. 2005, 1722, 183-188.

(161) Fraser, R.; MacRae, T.; Suzuki, E. Chain conformation in the collagen molecule. J. Mol. Biol. 1979, 129, 463-481.

(162) Bella, J. A new method for describing the helical conformation of collagen: Dependence of the triple helical twist on amino acid sequence. J. Struct. Biol. 2010, 170, 377-391.

(163) Flory, P. J.; Weaver, E. S. Helix [UNK] Coil Transitions in Dilute Aqueous Collagen Solutions1. J. Am. Chem. Soc. 1960, 82, $4518-4525$

(164) Collagen Market revenue to hit $\$ 6$ billion by 2026, Says Global Market Insights, Inc. https://www.globenewswire.com/news-release/ 2020/05/21/2036847/0/en/Collagen-Market-revenue-to-hit-6billion-by-2026-Says-Global-Market-Insights-Inc.html， (accessed 2021/02/20).

(165) Schmidt, M. M.; Dornelles, R. C. P.; Mello, R. O.; Kubota, E. H.; Mazutti, M. A.; Kempka, A. P.; Demiate, I. M. Collagen extraction process. Int. Food Res. J. 2016, 23, 913-922.

(166) Rashid, T. U.; Sharmeen, S.; Biswas, S.; Ahmed, T.; Mallik, A. K.; Shahruzzaman, M.; Sakib, M. N.; Haque, P.; Rahman, M. M. Polymers and Polymeric Composites: A Reference Series; Springer International Publishing, 2018; pp 1-41.

(167) Sionkowska, A. Current research on the blends of natural and synthetic polymers as new biomaterials: Review. Prog. Polym. Sci. 2011, 36, 1254-1276. 
(168) Barbani, N.; Bertoni, F.; Ciardelli, G.; Cristallini, C.; Silvestri, D.; Coluccio, M.; Giusti, P. Bioartificial materials based on blends of dextran and poly(vinyl alcohol-co-acrylic acid). Eur. Polym. J. 2005, 41, 3004-3010.

(169) Sionkowska, A.; Kaczmarek, H.; Wiśniewski, M.; Kowalonek, J.; Skopinska, J. Surface characteristics of UV-irradiated collagen/PVP blended films. Surf. Sci. 2004, 566-568, 608-612.

(170) Alexy, P.; Bakoš, D.; Hanzelová, S.; Kukolíková, L.; Kupec, J.; Charvátová, K.; Chiellini, E.; Cinelli, P. Poly(vinyl alcohol)-collagen hydrolysate thermoplastic blends: I. Experimental design optimization and biodegradation behaviour. Polym. Test. 2003, 22, 801-809.

(171) Sionkowska, A.; Skopinska-Wisniewska, J.; Wisniewski, M. Collagen-synthetic polymer interactions in solution and in thin films. J. Mol. Liq. 2009, 145, 135-138.

(172) Rogovina, S. Z.; Vikhoreva, G. A. Polysaccharide-based polymer blends: Methods of their production. Glycoconjugate J. 2006, 23, 611-618.

(173) Sam, S. T.; Nuradibah, M. A.; Ismail, H.; Noriman, N. Z.; Ragunathan, S. Recent Advances in Polyolefins/Natural Polymer Blends Used for Packaging Application. Polym.-Plast. Technol. Eng. 2014, 53, 631-644.

(174) Deselnicu, V.; Deselnicu, D. C.; Vasilescu, A. M.; Crudu, M.; Albu, L. Polymer - collagen Biocomposites. Mater. Plast. 2015, 52, 159-164.

(175) Wang, H.; Boerman, O. C.; Sariibrahimoglu, K.; Li, Y.; Jansen, J. A.; Leeuwenburgh, S. C. Comparison of micro- vs. nanostructured colloidal gelatin gels for sustained delivery of osteogenic proteins: Bone morphogenetic protein-2 and alkaline phosphatase. Biomaterials 2012, 33, 8695-8703.

(176) Giusti, P.; Lazzeri, L.; Barbani, N.; Narducci, P.; Bonaretti, A.; Palla, M.; Lelli, L. Hydrogels of poly(vinyl alcohol) and collagen as new bioartificial materials. J. Mater. Sci.: Mater. Med. 1993, 4, 538542.

(177) Hoch, E.; Schuh, C.; Hirth, T.; Tovar, G. E. M.; Borchers, K. Stiff gelatin hydrogels can be photo-chemically synthesized from low viscous gelatin solutions using molecularly functionalized gelatin with a high degree of methacrylation. J. Mater. Sci.: Mater. Med. 2012, 23, 2607-2617.

(178) Ramaraj, B.; Rajalingam, P.; Radhakrishnan, G. Crosslinked latex blends based on gelatin: Synthesis, morphology, thermal, and mechanical properties. J. Appl. Polym. Sci. 1991, 43, 23-28.

(179) Ye, X.; Zhou, Y.; Chen, J.; Sun, Y. Synthesis and infrared emissivity study of collagen-g-PMMA/Ag@TiO2 composite. Mater. Chem. Phys. 2007, 106, 447-451.

(180) Zhang, Y.; Wang, Z.; Wang, Y.; Zhao, J.; Wu, C. Facile preparation of $\mathrm{pH}$-responsive gelatin-based core-shell polymeric nanoparticles at high concentrations via template polymerization. Polymer 2007, 48, 5639-5645.

(181) O'Connor, K. M.; Szajewski, R. P.; Bagchi, P. Control of pressure-fog with gelatin-grafted and case-hardened gelatin-grafted soft polymer latex particles. US Patent US5066572A, 1991.

(182) Honan, J. S.; Walters, J. B.; Whitesides, T. H. Gelatin and polymer latex dispersion coating compositions. US Patent US5731134A, 1998.

(183) Meyer, R.; Fowler, J. W. F. Vinylidene chloride-ethylenically unsaturated monomer-ethylenically unsaturated acid-gelatin emulsion polymerized coating composition. US Patent US3403116A, 1968.

(184) Luo, Y.; Wang, T. Protein Byproducts; Elsevier, 2016; pp 147160.

(185) Nonthanum, P.; Lee, Y.; Padua, G. W. Effect of -Zein on the Rheological Behavior of Concentrated Zein Solutions. J. Agric. Food Chem. 2012, 60, 1742-1747.

(186) Demir, M.; Ramos-Rivera, L.; Silva, R.; Nazhat, S. N.; Boccaccini, A. R. Zein-based composites in biomedical applications. J. Biomed. Mater. Res., Part A 2017, 105, 1656-1665.

(187) Bouman, J.; Belton, P.; Venema, P.; van der Linden, E.; de Vries, R.; Qi, S. Controlled Release from Zein Matrices: Interplay of Drug Hydrophobicity and pH. Pharm. Res. 2016, 33, 673-685.
(188) Dong, J.; Sun, Q.; Wang, J.-Y. Basic study of corn protein, zein, as a biomaterial in tissue engineering, surface morphology and biocompatibility. Biomaterials 2004, 25, 4691-4697.

(189) Weissmueller, N. T.; Lu, H. D.; Hurley, A.; Prud'homme, R. K. Nanocarriers from GRAS Zein Proteins to Encapsulate Hydrophobic Actives. Biomacromolecules 2016, 17, 3828-3837.

(190) Luo, Y.; Teng, Z.; Wang, Q. Development of Zein Nanoparticles Coated with Carboxymethyl Chitosan for Encapsulation and Controlled Release of Vitamin D3. J. Agric. Food Chem. 2012, $60,836-843$.

(191) Davidov-Pardo, G.; Joye, I. J.; McClements, D. J. Advances in Protein Chemistry and Structural Biology; Elsevier, 2015; pp 293-325.

(192) Paliwal, R.; Palakurthi, S. Zein in controlled drug delivery and tissue engineering. J. Controlled Release 2014, 189, 108-122.

(193) Chen, H.; Wang, J.; Cheng, Y.; Wang, C.; Liu, H.; Bian, H.; Pan, Y.; Sun, J.; Han, W. Application of Protein-Based Films and Coatings for Food Packaging: A Review. Polymers 2019, 11, 2039.

(194) Kasaai, M. R. Zein and zein -based nano-materials for food and nutrition applications: A review. Trends Food Sci. Technol. 2018, 79, 184-197.

(195) Tian, H.; Fu, X.; Zheng, M.; Wang, Y.; Li, Y.; Xiang, A.; Zhong, W.-H. Natural polypeptides treat pollution complex: Moisture-resistant multi-functional protein nanofabrics for sustainable air filtration. Nano Res. 2018, 11, 4265-4277.

(196) Lee, H.; Xu, G.; Kharaghani, D.; Nishino, M.; Song, K. H.; Lee, J. S.; Kim, I. S. Electrospun tri-layered zein/PVP-GO/zein nanofiber mats for providing biphasic drug release profiles. Int. J. Pharm. 2017, 531, 101-107.

(197) Khatri, M.; Khatri, Z.; El-Ghazali, S.; Hussain, N.; Qureshi, U. A.; Kobayashi, S.; Ahmed, F.; Kim, I. S. Zein nanofibers via deep eutectic solvent electrospinning: tunable morphology with super hydrophilic properties. Sci. Rep. 2020, 10, 15307.

(198) Deng, L.; Zhang, X.; Li, Y.; Que, F.; Kang, X.; Liu, Y.; Feng, F.; Zhang, $\mathrm{H}$. Characterization of gelatin/zein nanofibers by hybrid electrospinning. Food Hydrocolloids 2018, 75, 72-80.

(199) Ansari, A. Q.; Ansari, S. J.; Khan, M. Q.; Khan, M. F.; Qureshi, U. A.; Khatri, Z.; Ahmed, F.; Kim, I. S. Electrospun Zein nanofibers as drug carriers for controlled delivery of Levodopa in Parkinson syndrome. Mater. Res. Express 2019, 6, 075405.

(200) Li, S.; Wang, X.; Li, W.; Yuan, G.; Pan, Y.; Chen, H. Preparation and characterization of a novel conformed bipolymer paclitaxel-nanoparticle using tea polysaccharides and zein. Carbohydr. Polym. 2016, 146, 52-57.

(201) Hu, K.; Huang, X.; Gao, Y.; Huang, X.; Xiao, H.; McClements, D. J. Core-shell biopolymer nanoparticle delivery systems: Synthesis and characterization of curcumin fortified zein-pectin nanoparticles. Food Chem. 2015, 182, 275-281.

(202) Ji, N.; Hong, Y.; Gu, Z.; Cheng, L.; Li, Z.; Li, C. Preparation and Characterization of Insulin-Loaded Zein/Carboxymethylated Short-Chain Amylose Complex Nanoparticles. J. Agric. Food Chem. 2018, 66, 9335-9343.

(203) Hu, K.; McClements, D. J. Fabrication of biopolymer nanoparticles by antisolvent precipitation and electrostatic deposition: Zein-alginate core/shell nanoparticles. Food Hydrocolloids 2015, 44, 101-108.

(204) Patel, A. R.; Bouwens, E. C. M.; Velikov, K. P. Sodium Caseinate Stabilized Zein Colloidal Particles. J. Agric. Food Chem. 2010, 58, 12497-12503.

(205) Li, F.; Chen, Y.; Liu, S.; Qi, J.; Wang, W.; Wang, C.; Zhong, R.; Chen, Z.; Li, X.; Guan, Y.; Kong, W.; Zhang, Y. Size-controlled fabrication of zein nano/microparticles by modified anti-solvent precipitation with/without sodium caseinate. Int. J. Nanomed. 2017, 12, 8197-8209.

(206) Li, H.; Xu, Y.; Sun, X.; Wang, S.; Wang, J.; Zhu, J.; Wang, D.; Zhao, L. Stability, bioactivity, and bioaccessibility of fucoxanthin in zein-caseinate composite nanoparticles fabricated at neutral $\mathrm{pH}$ by antisolvent precipitation. Food Hydrocolloids 2018, 84, 379-388.

(207) Li, K.-K.; Yin, S.-W.; Yang, X.-Q.; Tang, C.-H.; Wei, Z.-H. Fabrication and Characterization of Novel Antimicrobial Films 
Derived from Thymol-Loaded Zein-Sodium Caseinate (SC) Nanoparticles. J. Agric. Food Chem. 2012, 60, 11592-11600.

(208) Bao, X.; Qian, K.; Yao, P. Oral delivery of exenatide-loaded hybrid zein nanoparticles for stable blood glucose control and -cell repair of type 2 diabetes mice. J. Nanobiotechnol. 2020, 18, 67.

(209) Luo, Y.; Zhang, B.; Whent, M.; Yu, L. L.; Wang, Q. Preparation and characterization of zein/chitosan complex for encapsulation of -tocopherol, and its in vitro controlled release study. Colloids Surf., B 2011, 85, 145-152.

(210) Wang, L.-J.; Yin, S.-W.; Wu, L.-Y.; Qi, J.-R.; Guo, J.; Yang, X.Q. Fabrication and characterization of Pickering emulsions and oil gels stabilized by highly charged zein/chitosan complex particles (ZCCPs). Food Chem. 2016, 213, 462-469.

(211) Li, S.; Huang, L.; Zhang, B.; Chen, C.; Fu, X.; Huang, Q. Fabrication and characterization of starch/zein nanocomposites with $\mathrm{pH}$-responsive emulsion behavior. Food Hydrocolloids 2021, 112, 106341.

(212) Zou, Y.; Guo, J.; Yin, S.-W.; Wang, J.-M.; Yang, X.-Q. Pickering Emulsion Gels Prepared by Hydrogen-Bonded Zein/Tannic Acid Complex Colloidal Particles. J. Agric. Food Chem. 2015, 63, 7405-7414.

(213) Li, K.-K.; Zhang, X.; Huang, Q.; Yin, S.-W.; Yang, X.-Q.; Wen, Q.-B.; Tang, C.-H.; Lai, F.-R. Continuous preparation of zein colloidal particles by Flash NanoPrecipitation (FNP). J. Food Eng. 2014, 127, 103-110.

(214) Ebert, S.; Koo, C. K.; Weiss, J.; McClements, D. J. Continuous production of core-shell protein nanoparticles by antisolvent precipitation using dual-channel microfluidization: Caseinate-coated zein nanoparticles. Food Res. Int. 2017, 92, 48-55.

(215) Feng, J.; Zhang, Y.; McManus, S. A.; Qian, R.; Ristroph, K. D.; Ramachandruni, H.; Gong, K.; White, C. E.; Rawal, A.; Prud'homme, R. K. Amorphous nanoparticles by self-assembly: processing for controlled release of hydrophobic molecules. Soft Matter 2019, 15, 2400-2410.

(216) Xue, L.-H.; Xie, C.-Y.; Meng, S.-X.; Bai, R.-X.; Yang, X.; Wang, Y.; Wang, S.; Binks, B. P.; Guo, T.; Meng, T. Polymer-Protein Conjugate Particles with Biocatalytic Activity for Stabilization of Water-in-Water Emulsions. ACS Macro Lett. 2017, 6, 679-683.

(217) Zhang, M. Biological and Medical Physics, Biomedical Engineering; Springer Berlin Heidelberg, 2004; pp 83-143.

(218) Jaromir, K.; Atkins, G. M. Encapsulation. US Patent US3406119A, 1968.

(219) Hardy, J. G.; Scheibel, T. R. Composite materials based on silk proteins. Prog. Polym. Sci. 2010, 35, 1093-1115.

(220) Vendrely, C.; Scheibel, T. Biotechnological Production of Spider-Silk Proteins Enables New Applications. Macromol. Biosci. 2007, 7, 401-409.

(221) Sun, Y.; Shao, Z.; Hu, P.; Yu, T. Hydrogen bonds in silk fibroin-poly (acrylonitrile-co-methyl acrylate) blends: FT-IR study. J. Polym. Sci., Part B: Polym. Phys. 1997, 35, 1405-1414.

(222) Meira, G.; Gugliotta, L. M. Polimeros. Introducción a Su Caracterización y a La Ingeniería de La Polimerización (Polymers. Introduction to Its Characterization and Polymerization Engineering); Cátedra Ediciones UNL: Santa Fe, Argentina, 2019.

(223) Principles and Applications of Emulsion Polymerization; John Wiley \& Sons, Inc., pp 53-94.

(224) van Herk, A. Chemistry and Technology of Emulsion Polymerisation; Wiley, 2013.

(225) Kolthoff, I. M.; Miller, I. K. The Chemistry of Persulfate. II. The Reaction of Persulfate with Mercaptans Solubilized in Solutions of Saturated Fatty Acid Soaps1. J. Am. Chem. Soc. 1951, 73, 51185122.

(226) Khorana, H. G. The Chemistry of Carbodiimides. Chem. Rev. $1953,53,145-166$.

(227) Asua, J. M. Miniemulsion polymerization. Prog. Polym. Sci. 2002, 27, 1283-1346.

(228) Córdoba, C. A.; Ronco, L. I.; Barrios, C. E.; Gugliotta, L. M.; Minari, R. J. High Solid Acrylic-Melamine Latexes with Tunable Crosslinking Capability. Macromol. React. Eng. 2019, 13, 1800063.
(229) Kessel, N.; Illsley, D. R.; Keddie, J. L. The diacetone acrylamide crosslinking reaction and its influence on the film formation of an acrylic latex. J. Coat. Technol. Res. 2008, 5, 285-297.

(230) Chen, H.; Zhong, Q. Processes improving the dispersibility of spray-dried zein nanoparticles using sodium caseinate. Food Hydrocolloids 2014, 35, 358-366.

(231) Chang, C.; Wang, T.; Hu, Q.; Zhou, M.; Xue, J.; Luo, Y. Pectin coating improves physicochemical properties of caseinate/zein nanoparticles as oral delivery vehicles for curcumin. Food Hydrocolloids 2017, 70, 143-151. 